\title{
Poslušnik karađorđevićevskoga režima Franjo Urbany ${ }^{1}$
}

\author{
MARIO STIPANČEVIĆ \\ Hrvatski državni arhiv \\ Zagreb, Hrvatska \\ mstipancevic@arhiv.hr
}

Preustroj zagrebačkoga redarstva i njegovo stavljanje pod izravni nadzor beogradskih centara moći za nove je vlastodršce, čini se, bio jedan od važnijih ciljeva nakon uspostave Kraljevstva Srba, Hrvata i Slovenaca. Pogodnim za provođenje preustroja prepoznat je i odabran prijeratni zagrebački upravno-policijski službenik Franjo Urbany. U prilogu se raspravlja o njegovu profesionalnom i privatnom životu, s posebnim osvrtom na ključne događaje koji su ga obilježili. To se osobito odnosi na Urbanyjeve svjetonazorsko-ideološke mijene poput sudjelovanja u spaljivanju mađarske zastave 1895. te progona negdanjega sudruga iz toga pothvata Stjepana Radića nedugo nakon uspostave nove državne zajednice. Posebna je pozornost posvećena i ulozi Urbanyja u reorganizaciji zagrebačke policije te razlozima napuštanja mjesta ravnatelja Kraljevskoga redarstvenog ravnateljstva.

Ključne riječi: Franjo Urbany; biografija; zagrebačko redarstvo; monarhistička Jugoslavija

\section{Slaganje mozaika}

Povodeći se za riječima engleskoga književnika Samuela Johnsona da gotovo ne postoji život o kojemu razborito i vjerodostojno pripovijedanje ne bi bilo korisno, u ovome će prilogu biti govora o malo poznatom pravniku, državnom

\footnotetext{
$1 \quad$ Naslov priloga je neznatno izmijenjen navod Bosiljke Janjatović o F. Urbanyju objavljen u njezinu članku „Državne uze, post i samica”, 112.
} 
odvjetniku i ravnatelju zagrebačke policije Franji Urbanyju. Premda je svojevremeno obavljao visoke pravosudne i redarstvene dužnosti, u domaćim ga se historiografskim radovima rijetko doticalo. ${ }^{2}$

Slažući ulomke njegova životopisa i povezujući ih s osobama s kojima je ukrštao putove, na temelju arhivskih vrela i dostupne literature, donekle se mogu razabrati i obrisi šire društvene klime u Zagrebu od kraja XIX. do tridesetih godina XX. stoljeća. Podosta će se kazati i o ustrojstvu i djelovanju redarstva glavnoga hrvatskoga grada u tom razdoblju, što je iz raznih razloga također izmicalo ozbiljnijoj historiografskoj pozornosti. ${ }^{3}$

Opravdanost donošenja ovakvih biografskih prikaza, bez obzira na to koliko se oni činili samo sitnim ulomcima prošle stvarnosti, vezana je upravo za nedostatak šire znanstveno utemeljene slike o pojedinim sastavnicama ukupne društvene zbilje u prvim godinama postojanja starojugoslavenske države. Iako se primjenom ovdje zastupljena deskriptivnoga pristupa utemeljena najvećim dijelom na izvornom arhivskom gradivu ni izbliza ne daje cjeloviti uvid u prošla zbivanja, barem se donekle približava njihovu boljem razumijevanju. Uostalom, iza svake su društvene aktivnosti, koliko god to bilo zamagljeno u našim pogledima na prošlost, stajali pojedinci s imenom, prezimenom, osobnošću te više ili manje zanimljivim (i dokumentiranim) životom. Zbog svega toga i zadani cilj priloga razmjerno je skroman: s jedne strane prikazati ulomke životopisa jednoga zaboravljenog dionika zagrebačkoga mikrokozmosa u prvim desetljećima XX. stoljeća te istovremeno progovoriti o počecima preustroja represivnoga aparata starojugoslavenske države, u radu kojega je Franjo Urbany doživio profesionalni i životni vrhunac, nadajući se da će se time barem donekle upotpuniti praznine u našem poznavanju promatranoga razdoblja.

\section{Rođenje s pedigreom}

Urbanyjeva uspješna pravnička karijera ne treba čuditi. Za nju kao da je bio predodređen već dolaskom na svijet u obitelji oca Josipa, prisjednika Stola sedmorice, vrhovnoga sudišta u onodobnoj Hrvatskoj i Slavoniji, te majke Henrike rođ. Holjac, sestre poznatoga arhitekta i dugogodišnjega zagrebačkoga gradonačelnika Janka. Franjo je rođen 7. lipnja 1874. u Zagrebu, a na krštenju mu je kumovao djed Henrik Holjac, po kojemu je zasigurno i baštinio drugo ime. ${ }^{4}$ Bio je drugo dijete u obitelji.

\footnotetext{
2 Ti će prilozi biti navedeni u tekstu, pa ih ovdje ne treba posebno nabrajati.

Više o ovome vidi u: STIPANČEVIĆ, „Stranputice Joje Vragovića”, 101-102 i tamo navedenoj literaturi.

4 HR-HDA-1448-ZBMK, ZM-34C/98, Zagreb, župa sv. Marko, MKR 1866--1878.
} 
Josip i Henrika imali su, prema dostupnim vrelima, još najmanje sedmero potomaka. Nešto više od godinu i pol prije Franje, 12. studenog 1872., rođena je Štefanija (Slava). ${ }^{5}$ Mjesto njezina dolaska na svijet, a time i tadašnje prebivalište roditelja, nažalost nije poznato. Poživjela je do 1. rujna 1944., kada je kao „posjednica” preminula od upale pluća na svojoj zagrebačkoj adresi Mesnička $41 .{ }^{6}$ Nikada se nije udavala, a kao i majka Henrika (Henrietta) uživala je mirovinu („milostinju”) baštinjenu od oca, vijećnika Stola sedmorice.7 Treći potomak, Milutin, rođen je u Varaždinu 16. ožujka 1876. godine. ${ }^{8}$ Nije posve sigurno zašto je u to vrijeme obitelj prebivala u tom gradu. Najvjerojatnije se Josip s obitelji onamo preselio radi posla. U matičnim knjigama u Varaždinu rođene djece spominjan je naime kao ,judex penes judicium delegatum”, „assessor ad tribun[al] judic[iarium]”, ${ }^{10}$ odnosno „kr. vijećnik”11 - vjerojatno tamošnjega Kraljevskoga sudbenog stola.

Milutin je također imao zavidnu društvenu karijeru kao kemičar i srednjoškolski profesor. Nakon sedmogodišnjega pohađanja zagrebačke realne gimnazije, 1892. položio je ispit zrelosti. Od 1892. do 1894. odslušao je četiri semestra prirodnih nauka na Zagrebačkom sveučilištu, a od 1894. do 1896. pohađao predavanja na Visokoj tehničkoj školi u Beču, gdje je stjecao znanja iz anorganske i organske kemije, kemijske tehnologije, agrikulturne kemije, „roboznanstva” i „mikroskopije”. Godine 1896. na Bečkom sveučilištu odslušao je i semestar filozofije i pedagogije, a 1896./1897. na Zagrebačkom sveučilištu polazio je „prirodne nauke” i 1897. položio profesorski ispit iz kemije kao glavne struke te prirodopisa i fizike kao sporednih predmeta. Tijekom 1892. pohađao je „Kurz za plinsku kemiju” na Visokoj tehničkoj školi u Karlsruheu, a 1912. tečaj „Untersuchungsanstalt f. Nahrungs Genussmittel”12 u Beču.

Prvo zaposlenje dobio je 1896. u zagrebačkom kemijskom laboratoriju dr. S. Bošnjakovića, ${ }^{13}$ a od 1898. namješten je na Kraljevskom gospodarskom i šu-

\footnotetext{
HR-HDA-81-ZVOP, inv. br. 782/1918. (Henrietta Urbany).

HR-HDA-1448-ZBMK, ZM-34C/67, Zagreb, župa sv. Marko, MKU 1942.-1948.

HR-HDA-81-ZVOP, inv. br. 782/1918. (Henrietta Urbany).

HR-HDA-1448-ZBMK, ZM-34E/104, Varaždin, župa sv. Nikola, MKR 1868.-1878.

9 Sudac pri Delegiranom sudu (HR-HDA-1448-ZBMK, ZM-34E/104, Varaždin, župa sv. Nikola, MKR 1868.-1878.). Najvjerojatnije se radilo o prvostupanjskom kotarskom gradsko-delegiranom sudu (usp. SIROTKOVIĆ, „Pravosudne strukture u hrvatskim zemljama”, 18).

10 Prisjednik suda (HR-HDA-1448-ZBMK, ZM-34E/104, Varaždin, župa sv. Nikola, MKR 1868.-1878.).

11 HR-HDA-1448-ZBMK, ZM-34E/104, Varaždin, župa sv. Nikola, MKR 1878.-1891.

12 Zavod za istraživanje hrane.

13 Vjerojatno dr. Srećko Bošnjaković (1865. - 1907.), prvi hrvatski enokemičar, utemeljitelj i vlasnik Javnoga kemijskog laboratorija za istraživanje vina, poslije preimenovanog u Kraljevski hrvatsko-slavonski zemaljski kemijsko analitički zavod, koji je prerastao u Enološki zavod (usp. „Bošnjaković, Srećko”).
} 
marskom učilištu, odnosno Višem gospodarskom učilištu u Križevcima, gdje je predavao opću anorgansku i organsku kemiju, analitičku kemiju i analitičke vježbe te botaniku, mineralogiju i meteorologiju. Od 1914. do 1919. službovao je pri zagrebačkoj gradskoj plinari kao tehnički kemičar, a 1918. imenovan je i stalnim sudskim vještakom u kemijskoj struci u nadležnosti Kraljevskoga sudbenog stola u Zagrebu. Godine 1920./1921. kemiju i kemijsku tehnologiju predavao je na Trgovačkoj akademiji u Zagrebu, a 1922., uz veliki otpor uglednoga kemičara Vladimira Njegovana, namješten je i za honorarnoga docenta organske kemijske tehnologije na zagrebačkoj Kraljevskoj tehničkoj visokoj školi. Tu dužnost međutim nije mogao preuzeti „zapriječen istupom studenata, koji su izjavili, da njegova predavanja polaziti neće”, te je dodijeljen prof. Franji Hanamanu, odnosno njegovu laboratoriju. Uslijed spomenutih prilika, 1923. odluka o Urbanyjevoj honorarnoj docenturi stavljena je izvan snage. Iste je godine premješten u zagrebačku Kraljevsku III. realnu gimnaziju, ${ }^{14}$ gdje je dočekao umirovljenje u travnju 1935. godine. ${ }^{15}$

Tijekom radnoga vijeka objavio je brojne priloge u domaćim časopisima nastojeći popularizirati kemiju te razvijati vinarstvo i poljodjelstvo. ${ }^{16}$ Od 1914. bio je oženjen Štefanijom rođ. Briški, s kojom je imao sina Milutina, rođenog dvije godine poslije. ${ }^{17}$ Preminuo je u Zagrebu 7. srpnja 1955. godine. ${ }^{18}$

Sljedeći po redu član obitelji, Vladimir, rođen 13. prosinca 1877. također u Varaždinu, ${ }^{19}$ preminuo je od tuberkuloze kao neoženjeni „ovlašteni civilni mjernik" u dobi od 32 godine 10. svibnja 1909. u Zagrebu. ${ }^{20}$ Pored Milutina i Vladimira, u Varaždinu su rođeni i Emilij (8. ožujka 1879.) - preminuo nešto prije prvoga rođendana u veljači 1880., ${ }^{21}$ te Helena (18. srpnja 1880.), koja je poživjela samo nekoliko dana po rođenju. ${ }^{22}$

Dva posljednjerođena potomka u obitelji životne su putove završila u naponu snage. Kamilo je umro u Zagrebu 19. siječnja 1920. u 34. godini kao „neoženjeni posebnik” od uznapredovale tuberkuloze ${ }^{23}$ poput starijega mu brata Vladimira jedanaest godina prije, a Marijan ( ${ }^{\star}$ Zagreb, 7. rujna 1886.), ${ }^{24}$ po zanimanju gimnazijski profesor (najprije zemunske, a zatim i karlovačke

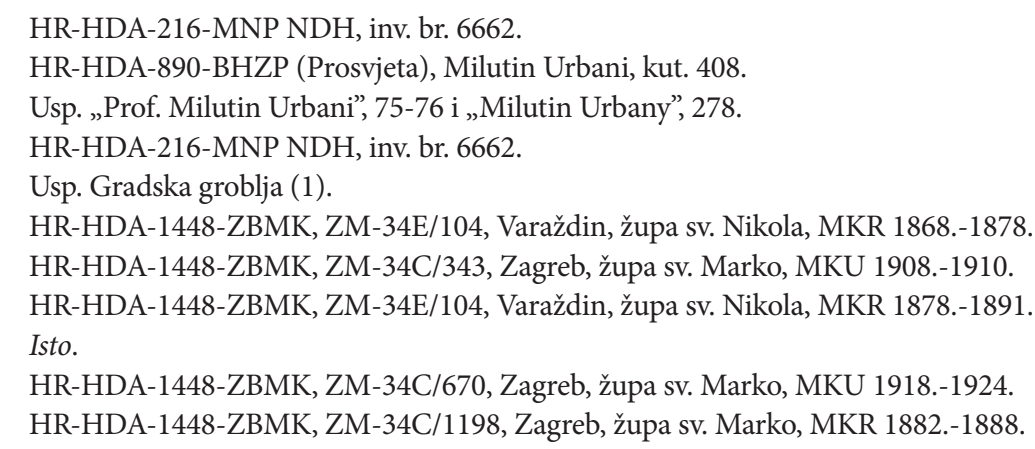


gimnazije), kao carski i kraljevski pričuvni poručnik 53. pješačke pukovnije poginuo je u Srbiji 24. rujna 1914. zapovijedajući vodom u navalnim borbama u okolici Crnoga vrha, odnosno pri zaposjedanju položaja na „Mrtvom briegu”. ${ }^{25}$ Marijanu je u braku s bankarskom činovnicom Helenom (Jelkom) rođ. Šafranek posmrtno rođen istoimeni sin, ${ }^{26}$ poslije sveučilišni profesor, prevoditelj, leksikograf te vrsni stručnjak za pomorsko nazivlje na hrvatskom i engleskom jeziku. ${ }^{27}$

Glava obitelji, Josip Urbany, poživio je do 63. godine i preminuo u Zagrebu 12. prosinca 1900. od ovapnjenja arterija („Athermatosis art.”). ${ }^{28}$ Supruga ga je nadživjela dva desetljeća. Umrla je samo tri dana nakon sina Kamila, 22. siječnja 1920., od ateroskleroze i kronične upale bubrega. ${ }^{29}$

\section{„Abcug Magjari”}

Iako za to nemamo izravnoga svjedočenja, Franjo je najvjerojatnije kao i njegov nešto mlađi brat Milutin pučku školu pohađao u rodnome gradu. Obrazovanje je nastavio u Kraljevskoj velikoj gimnaziji, stječući svjedodžbu zrelosti 1892. godine..$^{30}$ Iste je godine upisao Pravoslovni i državoslovni fakultet, koji je redovito pohađao do ljetnoga semestra školske godine 1894./1895. ${ }^{31}$ Tada je uslijedio prekid Urbanyjeva studiranja ${ }^{32}$ zbog sudjelovanja u studentskim prosvjedima protiv službene mađarske politike, uobličene u Khuen-Héderváryjevo banovanje, prigodom posjeta cara i kralja Franje Josipa Zagrebu sredinom listopada 1895. godine. Ti su događaji, kao što je poznato, vrhunac dosegnuli spaljivanjem mađarske zastave na središnjem zagrebačkom trgu. ${ }^{33}$

Urbany se našao među pedeset četvoricom hrvatskih sveučilištaraca optuženih za spomenute prosvjede, a bio je i među dvadeset osmoricom koji su na ročišste održano na Kraljevskome sudbenom stolu od 11. do 16. studenog 1895. dovedeni iz gradskoga zatvora. Kao 22. u nizu, bio je optužen da je 16. listopada 1895. između 11 i 12 sati u povorci stigao na Jelačićev trg te ondje uz poklike „Živio hrvatski kralj, slava Jelačiću, Abcug Magjari” zajedno s ostalim

25 Usp. BillionGraves (1); „Marijan Urbany”, Jutarnji list (Zagreb), 2. 11. 1914., 1-2; „Pali hrvatski junaci”, Sloga (Karlovac), 25. 10. 1914., 1; „Marijan Urbany”, Obzor (Zagreb), 18. 10. 1914., 2.

26 HR-HDA-890-BHZP (Prosvjeta), Marijan Urbani, kut. 408.

27 Usp. „Urbany, Marijan”.

28 HR-HDA-1448-ZBMK, ZM-34/341, Zagreb, župa sv. Marko, MKU 1897.-1900.

29 HR-HDA-1448-ZBMK, ZM-34C/343, Zagreb, župa sv. Marko, MKU 1908.-1910.

30 HR-HDA-890-BHZP, inv. br. 238.

31 HR-HDA-501-PF, Knjige redovitih slušača br. 32-34.

32 Usp. HR-HDA-501-PF, Knjige redovitih slušača br. 34

33 Usp. Hrvatski djaci pred sudom, 6, 9-10. (U optužnici i presudi Urbany je navođen i kao „Urbani” i kao „Urbany”, što je i poslije bio čest slučaj i s njim i s ostalim članovima obitelji.) Vidi i: JANJATOVIĆ, „Državne uze, post i samica”, 101. 
optuženim studentima sudjelovao u spaljivanju „ugarske trobojnice”, nastojeći tim činom „zavesti stanovnike državne, jedne proti drugima, na razdore neprijateljske". ${ }^{34}$

Nemoguće je ne zapitati se kako je na uhićenje reagirao Franjin otac, tada vijećnik Kraljevskoga banskog stola u Zagrebu. Gotovo sigurno ne s odobravanjem. Donekle se to može razabrati i iz Urbanyjeva iskaza, u kojemu je poricao pridruživanje prosvjednicima zbog političkih uvjerenja, pravdajući prisutnost događaju pukom znatiželjom. Prema riječima izrečenim pred istražnim sucem, nije znao o čemu se točno radi (!) te se povorci pridružio želeći vidjeti razvoj događaja, ali i zbog „kolegijalnosti” s ostalim sudionicima. Međutim, sud nije pretjerano povjerovao u Urbanyjeve navode, osobito zato što je u prethodnom iskazu danom gradskom redarstvu odmah po uhićenju kazao da je išao gledati „palenje zastave”, što nitko u povorci nije tajio, a sucu je i sam priznao da je bio toliko blizu središnjega čina demonstracija da je tom prilikom na nj pao komadić zapaljenoga stijega. ${ }^{35}$ Doduše, čini se da Urbany doista nije bio sudionikom pripremnih događaja na sveučilištu kada se dogovarao prosvjed. Povorci se pridružio tijekom njezina prolaska kroz Frankopansku ulicu, a prema vlastitom iskazu, nije izvikivao ni spomenute parole. S druge strane, iako je otvoreno priznavao da je bio u neposrednoj blizini zapaljene zastave, pred sudom nije želio prokazati osobe izravno odgovorne za taj čin, tvrdeći da je „vidio samo, kada je gorila”. ${ }^{36}$

Premda nije bio jedan od vođa ni organizatora demonstracija, Urbany je 16. studenog 1895. s još 27 studenata osuđen na „strogi zatvor od tri mjeseca”. No i na taj je način prošao bolje od Stjepana Radića, osuđenog na šest, Gjure Balaška, osuđenog na pet, te još šest svojih kolega osuđenih na četiri mjeseca stroge zatvorske kazne. ${ }^{37}$ Kao što je spomenuto, posljedica te optužnice za osuđenike, pa tako i za Urbanyja, bila je i zabrana studiranja na Zagrebačkom sveučilištu.

\section{Pri Sudbenom stolu}

Kada je i gdje odslušao četvrtu godinu studija, nije poznato. Sigurno je jedino da ga na Pravoslovnom i državoslovnom fakultetu za godine 1896. 1900., kada je prema dostupnim vrelima dovršio pravnu naobrazbu, nisu vodili ni kao redovnoga ni kao izvanrednoga studenta. ${ }^{38}$ Nije naodmet spomenuti

Hrvatski djaci pred sudom, 8-10, 14.

Isto, 18-19.

Isto, 13, 68-69.

Isto, 278-279.

HR-HDA-501-PF, Knjige redovitih slušača br. 35-46. 
da i ostali sačuvani službeni dokumenti o tome šute. Kako god bilo, državni ispit „razdiela pravno povjestnoga” položio je u srpnju 1894., „razdiela sudstvenoga” u srpnju 1897. („s odlikom trgovačkog i mjembenog prava”) te „razdiela državno znanstvenog” u veljači 1899. godine. Još i prije polaganja posljednjega, Urbany je u rujnu 1898., možda i uz očevu pomoć ili barem preporuku, stupio u vježbenički odnos pri zagrebačkom Kraljevskom sudbenom stolu. Nakon polugodišnjega vježbeništva krajem veljače imenovan je „prislušnikom”, ${ }^{39}$ polažući nakon nekoliko dana i službenu prisegu. ${ }^{40}$

Na Kraljevskom sudbenom stolu zadržao se do ožujka 1900., kada je dodijeljen „kr. kotarskom sudu I. u Zagrebu”. Nekoliko dana potom s vrlo dobrim uspjehom položio je „sudački izpit”. Na kotarskom se sudu zadržao nešto duže od pet godina. Nekoliko dana prije Božića 1905. dodijeljen je na službovanje Kraljevskom državnom odvjetništvu u Zagrebu u funkciji zamjenika državnoga odvjetnika. ${ }^{41}$ Urbany se u službi očito snašao više nego dobro. U vrelima je navedeno da je u radu pokazivao „izvrstne sposobnosti te osobito poznavanje zakona, a uz to je svoje službene dužnosti vršio velikom marljivošću i povjerljivošću te se u i izvan ureda u svakom pogledu valjano i neprikorno ponašao”, ${ }^{42}$ što mu je moralo pomoći da u sljedećih sedam godina redovito napreduje u činovničkim i platnim razredima. Napokon, nakon napredovanja u zamjenika državnoga odvjetnika II. razreda 1907. i I. razreda 1909., ${ }^{43}$ u kolovozu 1912. dodijeljen mu je naslov kraljevskoga državnog odvjetnika. ${ }^{44} \mathrm{U}$ rujnu iste godine na tom je mjestu zamijenio dotadašnjega državnog odvjetnika Leona Kaurića, ${ }^{45}$ koji mu je tom prigodom ustupio ured. ${ }^{46}$

U nedostatku drugih podataka iz toga razdoblja nije naodmet spomenuti da je Urbany u svibnju 1914. pred zagrebačkim sudbenim stolom zastupao optužnicu protiv općinskoga bilježnika u Petrovini Nikole Dobrinića zbog zloporabe ovlasti i nezakonitoga oslobađanja od vojne obveze izvjesnoga Janka Šašeka, koji je uz njegovu pomoć početkom 1911. emigrirao u Ameriku. Dobrinić je zbog toga naposljetku osuđen na tri mjeseca strogoga zatvora i globu od 100 kruna. ${ }^{47}$ Nešto kasnije, u lipnju 1914., kao „Zamjenik državnog

\footnotetext{
39 Sudski pripravnik.

$40 \quad$ HR-HDA-890-BHZP, inv. br. 238.

41 HR-HDA-890-BHZP, inv. br. 238; HR-HDA-397-DN, Dosje Franjo Urbany, kut. 88.

42 HR-HDA-397-DN, Dosje Franjo Urbany, kut. 88.

43 Isto.

44 HR-HDA-890-BHZP, inv. br. 238.

45 Leon Kaurić (1871. - 1960.), dugogodišnji državni odvjetnik u Ogulinu, Zagrebu i Bjelovaru te od 1922. vijećnik Banskoga stola u Zagrebu. Više o njemu u: HR-HDA-397-DN, Dosje Leon Kaurić, kut. 86. Usp. i: BillionGraves (2).

46 HR-HDA-397-DN, Dosje Franjo Urbany, kut. 88.

47 „Htio ga osloboditi od vojničtva”, Jutarnji list, 6. 5. 1914., 4.
} 
odvjetnika" Urbany je podigao tužbu i protiv odvjetničkoga perovođe Milana Brođanca zbog pokušaja silovanja osmogodišnje djevojčice na zagrebačkom Zelengaju sredinom svibnja iste godine. Nakon tajne rasprave sud nije prihvatio dokaze optužbe za pokušaj silovanja, pa je optuženik osuđen na mjesec dana strogoga zatvora zbog prekršaja protiv javnoga ćudoređa. ${ }^{48}$ Ovdje valja spomenuti da nije posve jasno zašto je Urbany tek 10. kolovoza 1915. „imenovan [...] državnim odvjetnikom" i zašto se u dokumentu o imenovanju spominje kao „zamjenik državnog odvjetnika I. razreda” (kao i u postupku protiv Brođanca), kada to očito od 1912. nije bio. Čini se da je potonje imenovanje bilo „pravo”, za razliku od prvoga „naslovnog”. ${ }^{49}$

\section{Protiv velikosrpske propagande}

Urbany je u austrougarskoj vojsci služio kao jednogodišnji dobrovoljac. ${ }^{50}$ Dokumenti, nažalost, ne spominju u kojem razdoblju i pri kojoj postrojbi. Ako je suditi prema raspoloživim podacima, slijedu studiranja i početku službe, pretpostavka je da se to moralo dogoditi negdje između 1896. i 1900., dakle neposredno nakon događaja povezanih sa spaljivanjem mađarske zastave, izgona sa studija te dovršetka akademske naobrazbe. Možda je „dragovoljni” odlazak u vojsku bio i svojevrsna očeva reakcija na pribivanje demonstracijama i za to zarađenu zatvorsku kaznu, a možda i način da se potomak ugledne obitelji vrati među pravovjerne štovatelje Monarhije, poravnavajući si narušeni put $\mathrm{k}$ (očekivanim) uspjesima u državnoj službi.

Budući da je kao jednogodišnji dobrovoljac „izvršio propisane oružane vježbe”, kao pričuvni je poručnik „kad je rat proglašen mobiliziran”, a već 18 . kolovoza bio je „reklamiran”. ${ }^{51}$ Teško je sa sigurnošću dokučiti što se skriva iza potonje riječi. Ako ćemo ju tumačiti doslovce, Urbany je razvojačen nakon što je na poziv za pristupanje vojsci (i vjerojatno brzi odlazak na bojište u Srbiju) uložena nekakva vrsta žalbe. To ponovno miriše na odjeke očevih utjecajnih veza u višim porama onodobnoga hrvatskog društva, ali i onih koje je Urbany dotad sam stekao. Možda je, među ostalim, i zbog toga ostalo vrlo malo tragova o Franjinoj „karijeri” pričuvnoga poručnika. Ako je ta pretpostavka točna, teško joj se može prigovoriti jer su Urbanyjevi uskoro podnijeli najveću žrtvu za kralja i cara pogibijom još jednoga pričuvnog poručnika u obitelji - Marijana. Ipak, na temelju događaja koji su uslijedili vjerojatnije je da je Franjo iz

\footnotetext{
48 „M. Brodjanac osudjen”, Jutarnji list, 4. 6. 1914., 5.

49 HR-HDA-397-DN, Dosje Franjo Urbany, kut. 88. Usp. i: HR-HDA-81-ZVOP, inv. br. 407/1919. (Franjo Urbany).

50 HR-HDA-397-DN, Dosje Franjo Urbany, kut. 88.

51 Isto.
} 
vojske na drugu dužnost povučen zbog „potreba službe”, odnosno da bi stručnošću i iskustvom pomagao u pozadinskim naporima, što je za državu bilo korisnije od upućivanja još jednoga pričuvnog časnika na bojišnicu.

Dostupna nam vrela naime govore da je Urbany tijekom rata odigrao važnu ulogu u austrougarskoj „protuobavještajnoj službi” (defensiven Kundschaftsdienst), utemeljenoj u svibnju 1914., odnosno njezinu zagrebačkom odvjetku zaduženom za protuobavještajnu djelatnost na području Hrvatske i Slavonije, s posebnim zadatkom sprječavanja obavještajnoga rada s područja Srbije. ${ }^{52}$ Temeljni zadaci Središnje defenzivno doglasne službe (SDDS) bili su, među ostalim, prikupljanje podatka o postojanju sumnje u počinjenje kaznenih djela poput neovlaštenoga snubljenja vojnih osoba na povredu vojničkih dužnosti, uhođenja, sporazumijevanja s neprijateljem, veleizdaje, uvrede veličanstva ili članova carskoga i kraljevskoga doma, ometanja javnoga mira, djelovanja na nasilnoj promjeni sustava vladanja ili odcjepljenja nekoga od dijelova jedinstvene državne zajednice. Nakon što bi se u SDDS-u ustanovilo postojanje sumnje o takvu djelovanju, postupak bi se prepuštao redarstvu ili kotarskim vlastima te državnom odvjetništvu radi nastavljanja istrage, koja je mogla voditi prema podizanju optužnice i sudskom procesu. ${ }^{53}$ Čini se da je upravo zbog te spone SDDS-a i državnoga odvjetništva Urbany dospio u protuobavještajno društvo.

Naime, SDDS je 19. prosinca 1915. utemeljio „istražno povjerenstvo” zaduženo za isljeđivanje tragova velikosrpske propagande s Urbanyjem na čelu, s neposrednim zadatkom pregledavanja sigurnosno važne dokumentacije zaplijenjene ili pronađene u Srbiji. Osim Urbanyja, članom povjerenstva imenovan je i Vladin perovodni činovnik Teodor Peičić, a prema potrebi mogli su mu biti priključeni i redarstveni agenti Julije Rimay te Juraj Krainpler. ${ }^{54}$ Članovi toga povjerenstva, pored središnjih zadataka, morali su pomagati beogradskoj Vojnoj glavnoj upravi (Militär General Gouvernement) u njezinu radu. S druge strane iste su osobe u skladu s odredbama Vojne uprave mogle poduzimati pretrese i istrage udruženja i institucija povezanih s osobama ili društvima s područja Hrvatske i Slavonije, a o mogućim saznanjima obavještavati SDDS. Članovi povjerenstva osobito su upozoreni na praćenje djelatnosti sokolskih društava u Srbiji, zemljoradničkih zadruga i društva „Privrednik”, socijalističkoga pokreta i njegova organa Borbe te projugoslavenskoga lista Pijemont.

\footnotetext{
52 KOTA, „Uloga Središnje defenzivno doglasne službe”, 13-14.

53 Isto, 20-21.

54 Umjesto Krainplera u Beograd je s Urbanyjem i Rimayem naposljetku poslan redarstveni činovnik Vladimir Šestak (usp. HR-HDA-79-UOZV-SDDS, 258/16, kut. 5703).
} 
Da je zadatak povjerenstva bio zamišljen ozbiljno, svjedoči Urbanyjeva obveza iscrpnoga izvješćivanja zagrebačke centrale u osmodnevnom razdoblju. ${ }^{55}$

Osnivanje povjerenstva podignuto je na višu razinu početkom 1916. kada je austrougarsko Vrhovno vojno zapovjedništvo obavijestilo Zemaljsku vladu u Zagrebu da se potpunom uspostavom Vojne glavne uprave u Beogradu pojavila potreba istraživanja veće količine važne dokumentacije dostupne nakon okupacije Srbije. Stoga je predloženo osnivanje zajedničkoga povjerenstva sa zadatkom poduzimanja takvih istraživanja, a Zemaljska je vlada zamoljena da se odaslani hrvatski predstavnici u Beogradu Urbany i Peičić uključe u rad povjerenstva Vrhovnoga vojnog zapovjedništva. ${ }^{56}$

To je doista učinjeno, pa je početkom 1916. Urbany podrobno izvještavao nadređene da je mješovito povjerenstvo izaslano u Beograd u predmetu isljeđivanja tragova velikosrpske propagande s obzirom na područje Hrvatske i Slavonije provelo izvide o djelatnosti članova „Saveza dobrovoljaca u Kraljevini Srbiji”, kao i o podanicima Monarhije koji su postali pripadnicima „I. čete dobrovoljaca srbijanske vojske”. Istovremeno su u uredništvu beogradskoga časopisa Balkan pronađene molbe žitelja jugoistočnoga Srijema koji su nakon povlačenja protivničke vojske s njom prešli u Srbiju. Naime, u Beogradu je zbog toga osnovan „Odbor za pomoć prekosavskim Srbima”, a uredništvo Balkana prikupljalo je priloge za izbjeglice iz Srijema „koji su ispred nasilja austromađarskog potražili utočište u krilu majke Srbije”. Posve jasno, u izvještaju o tim molbama posebno su isticane osobe koje su dragovoljno pristupile srbijanskoj vojsci. ${ }^{57}$

Po pitanju povezanosti velikosrpske propagande i Jugoslavenskoga odbora Urbany je uz izvještaj dostavio primjerke tiskopisa Tribuna u kojemu su bili objavljeni napisi o radu toga tijela. U brošuri Skerlićeva godišnjica uočio je da je Jugoslavenski odbor 22. travnja 1915. održao svečanu sjednicu u Nišu, kojoj su prisustvovali Jovan Banjanin i Frano Supilo. Dostavio je i brojeve Jugoslovenskoga glasnika, koji je tijekom 1915. izlazio u Nišu s ciljem oslobođenja i ujedinjenja Slovenaca, Hrvata i Srba i u kojemu su objavljivani članci austrougarskih podanika, članova Jugoslavenskoga odbora. ${ }^{58}$

Usto su provedeni izvidi koji su potvrdili ustrojavanje „sremskog četničkog odreda” sastavljenog od 296 žitelja Srijema prebjeglih u Srbiju, premeta-

\footnotetext{
55 KOTA, „Uloga Središnje defenzivno doglasne službe”, 331. Usp. i: HR-HDA-79-UOZVSDDS, 2817/15, kut. 5701.

56 KOTA, „Uloga Središnje defenzivno doglasne službe”, 333. Usp. i: HR-HDA-79-UOZVSDDS, 2817/15, kut. 5701.

57 KOTA, „Uloga Središnje defenzivno doglasne službe”, 333-334; HR-HDA-79-UOZV-SDDS, 258/16, kut. 5703.

58 KOTA, „Uloga Središnje defenzivno doglasne službe”, 362; HR-HDA-79-UOZV-SDDS, 258/16, kut. 5703.
} 
čine u uredništvima časopisa Politika, Pravda i Tribuna, udruženjima „Savez dobrovoljaca u kraljevini Srbiji”, „Crna ruka”, „Društvo socijalista”, „Slobodna zidarska loža Trezvenost”, tiskarama „Nakladna tiskara Gece Kona”, „Kr. drŽavna štamparija”, „Nova štamparija Ljube Davidovića”, „Štamparija Dimitrijević”, svratištima „Paris” i „Moskva” te kod „brojnih zvaničnih i privatnih osoba Srbije” poput pukovnika Petra Mišića, generala Bože Jankovića i Petra Živkovića, književnika Branislava Nušića, sveučilišnoga profesora Jovana Cvijića, bivših ministara Vladana Đorđevića i Jovana Avakumovića, predsjednika Skupštine Ljube Davidovića i dr. Iz spomenutoga izvještaja može se razabrati da je od 20. prosinca 1915. - kada su izaslanici zagrebačkoga SDDS-a stigli u Beograd - do 10. siječnja 1916. obavljeno ukupno 48 premetačina, ${ }^{59}$ što zasigurno govori o ozbiljnosti s kojom su Urbany i ostali članovi mješovitoga povjerenstva za suzbijanje velikosrpske propagande pristupili zadanim obvezama.

Na temelju raspoloživih arhivskih vrela nije nažalost moguće potpuno rekonstruirati Urbanyjevu djelatnost za sve četiri ratne godine. Kao što je rečeno, od prosinca 1915. djelovao je u okvirima SDDS-a, a opravdano je pretpostaviti da je na sličan način nastavio i do kraja rata. O tome svjedoči banov nalog od 3. travnja 1917. da kao izaslanik Zemaljske vlade istraži podatke o velikosrpskoj propagandi i vezama podanika banske Hrvatske sa srbijanskim krugovima prema podacima u spisima pronađenim kod srbijanskih oblasti i tamošnjih službenika, na temelju kojega je podnio djelomično izvješće 15 . srpnja 1917., prilažući mu i prijepise pronađenih dokumenata koji su mogli biti zanimljivi za istražni, sudski ili policijski postupak. ${ }^{60}$ Urbanyjev nepotpuno dostupan izvještaj o istraživanju u srpskim vojnim arhivima od 13. ožujka $1918 .{ }^{61}$ pokazuje da je i kraj ratnih djelovanja dočekao na spomenutom položaju. Je li i sam početak velikoga sukoba proveo u SDDS-u, na što bi moglo upućivati razvojačenje u kolovozu 1914. i kasniji navodi o služenju austrougarske vojske od kraja srpnja 1914. do posljednjih dana listopada $1918 .{ }^{62}$ zasad nije $^{2}$ moguće tvrditi bez znatne doze opreza.

Kako god bilo, do samoga je kraja zdušno služio Monarhiji, a protiv svojih budućih nalogodavaca i suradnika. Tako su njegovi izvidi iz 1918. bili upotrijebljeni protiv izvjesnoga Lazara Bikickog iz Sivca u Bačkoj zbog sumnje na

\footnotetext{
59 KOTA, „Uloga Središnje defenzivno doglasne službe”, 333-334; HR-HDA-79-UOZV-SDDS, 258/16, kut. 5703.

60 KOTA, „Uloga Središnje defenzivno doglasne službe”, 423; HR-HDA-79-UOZV-SDDS, 3041/17, kut. 5719.

${ }_{61}$ Radi se o izvještaju zavedenom pod pisarničkom oznakom „402/18 sdds”, koji nije pronađen u cjelovitom obliku, nego su iz njega dostupni po potrebi izlučivani dijelovi vezani za pojedine slučajeve uhođenja velikosrpske propagande koji će biti spomenuti u nastavku.

62 Vidi poglavlje „Mirnije vode“.
} 
uhođenje u Mitrovici i okolnim naseljima u korist srbijanske vojske. U spisima preostalim iza raspuštenih ministarstava doista je pronađena dokumentacija koja je potvrđivala doušničko djelovanje Bikickog prije početka rata, odnosno njegove dojave o kretanjima i snazi austrougarske vojske u Srijemu. Iako Urbanyjev izvještaj nije izravno utjecao na osudu Bikickog na tri godine teške tamnice krajem 1917., zasigurno je pomogao u uvjerenju da je spomenuti pravedno osuđen zbog „uhodarstva” od 1912. do 1914. godine. ${ }^{63}$

Ostalo je također zabilježeno da je Urbany u tom razdoblju istraživao i zaplijenjene arhive sveučilišnoga profesora i narodnoga poslanika dr. Jovana Skerlića, ${ }^{64}$ profesora Mile Pavlovića ${ }^{65}$ predsjednika Vlade i ministra vanjskih poslova Nikole Pašića ${ }^{66}$ te udruženja „Narodna odbrana”. ${ }^{67} \mathrm{Da}$ je doista bio osobom od neupitnoga povjerenja vlasti te važan kotačić u obavještajnome sustavu Monarhije, svjedoči i činjenica da su se faksimili njegova potpisa kao dokazi vjerodostojnosti morali nalaziti na prijepisima (svih) dokumenata priloženih onodobnim izvješćima o isljeđivanju tragova neprijateljske djelatnosti na području Srbije. ${ }^{68}$

\section{Pokloni Bene Klobučarića}

Urbany je ipak, najvjerojatnije zbog ponašanja tijekom istrage „Saveza dobrovoljaca u Kraljevini Srbiji” te pripadnika „I. čete dobrovoljaca srbijanske vojske” krajem 1915. i početkom 1916., dospio u nezgodan položaj spram nadređenih. U siječnju 1916. Predsjedništvo Zemaljske vlade raspravljalo je o prijavi Državnoga odvjetništva u Mitrovici prema kojoj je Urbany prilikom „povjerenstvenog uredovanja u Sremu” protuzakonito priskrbio „svu silu [u] kradenih stvari”, među ostalim „veliki pirotski ćilim” i više tisuća poštanskih maraka, te u Zemunu dao "pobudu fukari” za pljačku jedne tamošnje tiskare. ${ }^{69}$ Premda je u potpisu prijave bilo samo prezime „Vinković” te joj se nije mogao ustanoviti autor, ${ }^{70}$ službenici Zemaljske vlade pristupili su joj prilično ozbiljno. Odmah su zatražili očitovanje Urbanyja, ali i vijećnika Banskoga stola Ivana Žigovića, koji je s njim obavljao naložene dužnosti u Srijemu. Urbany je u iskazu rekao da je od „oficijela Bene Klobučarića, pridieljenog zapovjedničtvu

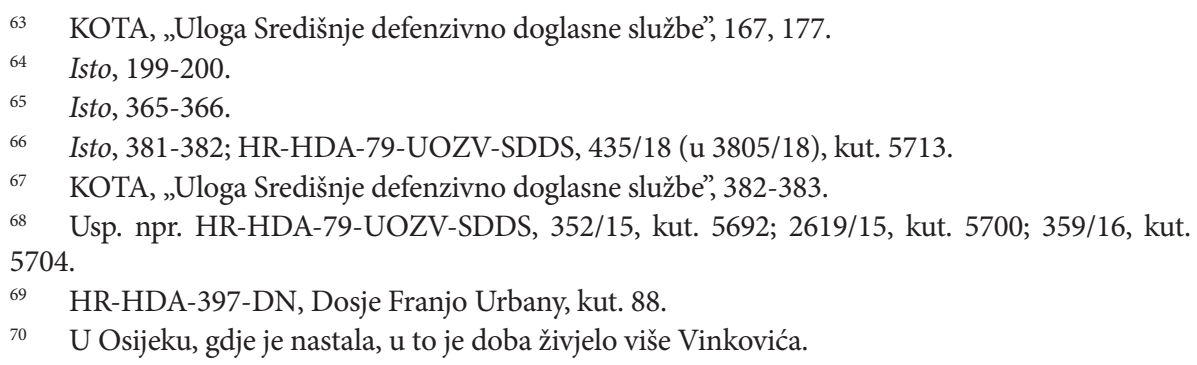


mostne glave u Beogradu”, na dar primio dva „tuljka” od šrapnela i jedan obični mali ćilim. Pored toga prisvojio je „njekoliko omota rabljenih austrijskih poštanskih maraka” koje je njemu i Žigoviću izvjesni „financijalni savjetnik” Kovač, inače „sekvestar sekvestrirane imovine veleizdajnika”, stavio na raspolaganje. Nadalje je navodio da je satnika Stipetića, ${ }^{71}$ koji je za svoju „vojnu upravu” potraživao tiskarska slova, „upozorio” na zatvorenu tiskaru tada već pokojnoga Jovana Prlje iz Zemuna. Nekoliko dana poslije Urbany je Klobučarića i natporučnika Kurelića odveo do redarstva, a zatim i do same tiskare, od koje se, prema vlastitim riječima, brzo udaljio uvidjevši da Klobučarić u nju pokušava nasilno ući nogom obijajući vrata. Budući da je Urbanyjev sudrug u administriranju u Srijemu Žigović u cijelosti potvrdio sve njegove navode, kazneni postupak nije pokrenut iako je za tužbu zadužen službenik Zemaljske vlade na kraju izvještaja napomenuo da bi valjalo provjeriti kako je Klobučarić došao u posjed ćilima koji je darovao Urbanyju. ${ }^{72}$

To nije određeno bezrazložno jer to nije bio jedini slični zabilježen slučaj takve Klobučarićeve rabote tijekom okupacije Srbije. U studenome 1920. Odelenje javne bezbednosti Ministarstva unutarnjih dela uputilo je Kraljevskom redarstvenom povjereništvu u Zagrebu dopis u kojem se tražila premetačina Klobučarićeva stana radi povratka knjiga „nemačkih i francuskih pol.[icijske] sadržine” koje je sredinom 1916. otuđio iz stana Vase Lazarevića, ${ }^{73}$ prijeratnoga „člana Uprave Grada Beograda”. Redarstvene su vlasti tada nadležnome ministarstvu odgovorile da se premetačina i povratak knjiga ne mogu provesti budući da Klobučarić u glavnom hrvatskom gradu više nije imao ni stan ni pohranjeno pokućstvo jer je „2. februara 1918 supruga Bene Klobučarića sve njegove stvari odpremila u Požun, gdje je Klobučarić u službi bio". ${ }^{74}$

Ne treba čuditi što vlasti u Zagrebu nisu imale pretjerano povjerenje u svojega „javnog urednika”"75 Klobučarića. Radilo se o doista osebujnu karakteru. Nakon okupacije Srbije tamošnjoj je Vojnoj upravi priključen kao dotadašnji policijski „šef detektiv” zagrebačke policije, a u „oficijela Klobučarića” spomenuta je uprava, za razliku zagrebačkih vlasti, imala „najveće povjerenje” iako se radilo osobi, najblaže rečeno, sumnjive prošlosti. ${ }^{76}$

\footnotetext{
71 Vjerojatno Vilim Stipetić, koji je nakon rasapa Monarhije zajedno s Klobučarićem stupio u emigrantski, ilegalni i antijugoslavenski Hrvatski komitet okupljen oko zagrebačkoga odvjetnika dr. Ivice Franka, sina poznatijega političara Josipa (usp. JANJATOVIĆ, Politički teror u Hrvatskoj, 192-194).

72 HR-HDA-397-DN, Dosje Franjo Urbany, kut. 88.

73 Istoga onog s kojim će Urbany sedam godina poslije usko surađivati i koji će hvaliti njegovu reorganizaciju zagrebačkoga redarstva! Vidi poglavlje „Ravnanje redom“.

74 HR-HDA-78-PRZV, 6-14, 19838/1920.

75 HR-HDA-397-DN, Dosje Franjo Urbany, kut. 88.

76 MIRNIK, „Referat dr. Viktora Alexandera caru Karlu”, 409.
} 
Prema izvještaju Policijskoga komesarijata u Zagrebu od 20. rujna 1917., bio je upisan u maticu rođenih u Brežicama kao nezakoniti sin Malvine Klobučarić, iako mu je majka u trenutku poroda bila u braku. Od naobrazbe je imao samo pučku školu. Bio je potjeran iz zagrebačkoga Plemićkoga konvikta, morao je napustiti gimnaziju i realnu školu, poljodjelsku školu u Grottenhofu, trgovačku školu u Grazu, kao i osnovnu vojnu školsku ustanovu u Požunu. ${ }^{77}$ Njegov skrbnik dr. Šime Mazzura predao je potkraj 1898. i početkom 1899. zahtjev zagrebačkome sirotištu da ga se zbog „nemarnosti, lijenosti i drugih loših svojstava, krivotvorenja svjedodžbi, prevarničkih dugova te druženja s nećudorednim ženskama, smjesti u neki popravni zavod”. ${ }^{78}$ Zagazivši u treće desetljeće života, završio je praksu za „zubotehničara” i tim se poslom neko vrijeme bavio u Koprivnici, gdje je naposljetku optužen zbog „krivog liječenja”. Pomoću rođaka došao je „do gradskog namještenja u Koprivnici”, postajući „nadzornikom svjetiljki pa nadzornikom u ciglani te nadzornikom poreza na potrošnju”, a 1. travnja 1913. „gradskim kapetanom”. ${ }^{79}$ Međutim i tamo je ubrzo „postao nemoguć, pa su protiv njega uslijedili brojni novinski napisi, zbog kojih je najprije premješten u Bjelovar i Križevce, a 10. studenog 1914. dodijeljen je „Kraljevskom policijskom Komesarijatu u Zagrebu”. Pored svega toga neovlašteno se izdavao za plemića i nosio časničku odoru. ${ }^{80}$

Pred početak rata spominjao se i kao „Vladin povjerenik za Hrvatsku”, ${ }^{81}$ a u listopadu 1914. skupa s kasnijim ravnateljem zagrebačke policije Jankom Bedekovićem te agentom Mankom Gagliardijem terorizirao je srpsko stanovništvo Posavine i Podravine zbog tobožnje špijunaže protiv Monarhije. ${ }^{82}$ Od sredine studenoga iste godine nalazio se u vojnoj obrambenoj doglasnoj službi, ${ }^{83}$ a krajem studenoga 1915. postavljen je „kod zapovjedničtva mostne utvrde u Beogradu". ${ }^{84}$

Nakon svršetka rata taj je „zloglasni policijski činovnik” i pouzdanik okupacijske vlasti u Srbiji brzo pobjegao preko granice. U Austriji je po proglaše-

\footnotetext{
77 Isto.

78 Isto.

80 MIRNIK, „Referat dr. Viktora Alexandera caru Karlu”, 409.

81 RAHTEN, „Ozadja iz okoliščine Žibertove teorije zarote”, 14.

82 STIPANČEVIĆ, „U obrani ‘̌uuftova i dreka”', 219-221.

83 HR-HDA-78-PRZV, II, 8244/1914.

84 HR-HDA-78-PRZV, 1-6, 2060/1917.
}

79 Ponešto o Klobučariću kao „gradskom redarstvenom povjereniku u Koprivnici” i naposljetku odbačenoj disciplinskoj istrazi iz sredine svibnja 1913. uperenoj protiv njega vidi u: HR-HDA-890BHZP, inv. br. 6512. Na drugom se mjestu pak spominje da je za „Vargovića [gradonačelnik 1906. 1913., op. M. S.] Koprivnica [...] dobila pravo svog gradskog redarstva, a kapetan redarstva Beno pl. Klobučarić uredio ga je na najbolji način” (KOLAR-DIMITRIJEVIĆ, „Jedno viđenje povijesti grada Koprivnice”, 16). Klobučarić se spominjao i kao jedna od osoba zaslužnih za razotkrivanje ilegalne tiskare novca koprivničkoga fotografa V. Kolombara i križevačkoga graditelja orgulja V. Erhatića u Koprivnici 1912. (KOLAR-DIMITRIJEVIĆ, Povijest novca u Hrvatskoj, 131, bilj. 228). 
nju Kraljevstva Srba, Hrvata i Slovenaca zajedno s Gagliardijem i Stipetićem utemeljio nekakvu seljačku vojnu postrojbu („Bauernkommando”) u neutralnoj zoni južno od Graza, odnosno graničnim područjima između kasnije slovenske i austrijske Štajerske, ${ }^{85}$ a nešto kasnije pridružio se i emigrantskom $\mathrm{Hr}$ vatskom komitetu na čelu s bivšim narodnim zastupnikom Ivom Frankom. ${ }^{86}$

Klobučarić je u emigraciji, odnosno Hrvatskom komitetu, koji je poslije postao dijelom ustaške emigracije, bio aktivan do Drugoga svjetskog rata. Sam Pavelić o njemu je kasnije pisao kao o „vrlo spretnom i vanrednom konspiratoru” ${ }^{87} \mathrm{Da}$ je doista bio poznat u emigrantskim krugovima, svjedoče dokumenti obavještajne službe Kraljevine Jugoslavije iz srpnja 1939., u kojima je zabilježeno njegovo djelovanje u Grazu, kao i sumnja da je suradnik njemačke obavještajne službe ${ }^{88}$ Prema nekim saznanjima, Klobučarić se na čelu tzv. Hrvatske legije krajem svibnja 1941. vratio u Zagreb, ${ }^{89}$ no njegove daljnje akcije u Hrvatskoj nisu poznate. Najvjerojatnije se vratio obavještajnim poslovima budući da se u travnju 1944. spominjao kao glavni pouzdanik njemačke vojne obavještajne službe (Abwehr) za Hrvatsku te ujedno „njihov kurir za Vojskovođu [Slavka Kvaternika, op. M. S.] i za Peštu glavna veza”.$^{90}$ Da je to najvjerojatnije bilo točno, svjedoči i izvješće koje je početkom siječnja 1945. kao „agent njemačkog Abwehra” u vezi sa saznanjima o puču Lorković-Vokić Klobučarić uputio generalu Edmundu Glaiseu von Horstenauu u Beč..$^{11}$ Benina poslijeratna sudbina, nažalost, nije poznata. Ne bi čudilo da su ga karakter, iskustvo i veze stečene u obavještajnom podzemlju spasili od težih posljedica.

\section{U novome društvu}

Unatoč dugotrajnom obavještajnom radu u Srbiji tijekom ratnoga razdoblja, Urbany je u novi državni aparat uključen bez vidnijih posljedica, nastavljajući nizati službeničke uspjehe. Od donedavnoga okupacijskog isljednika doskora je postao važnom polugom beogradskih vlasti. Najprije je 1919. i 1920. promaknut u viši platni, odnosno činovnički razred, a krajem kolovoza 1921. imenovan kraljevskim banskim savjetnikom, kao uvod u povjeravanje uprave Kraljevskim redarstvenim ravnateljstvom. ${ }^{92}$ Naravno, svemu je prethodilo

\footnotetext{
HR-HDA-78-PRZV, 6-14, 2014/1919. Usp. i: STIPANČEVIĆ, „Vampir iz Petrinjske”, 113-114.

HORVAT, Hrvatski panoptikum, 217.

KRIZMAN, Pavelić u bjekstvu, 240.

${ }^{8}$ DESPOT, „Povjerljivi izvještaji”, 330. Usp. i podatak o Klobučarićevu djelovanju u „ustaškoj grupi u Trećem Reichu" tijekom 1939. (JELIĆ-BUTIĆ, Ustaše i Nezavisna Država Hrvatska, 33).

${ }_{89}$ KRIZMAN, Ante Pavelić i ustaše, 420. Usp. i: Hrvatski narod (Zagreb), 27. 5. 1941., 6.

$90 \quad$ KRIZMAN, Ustaše i Treći Reich, 360-361.

91 KEVO, „Djelatnost Međunarodnog odbora Crvenog križa”, 240.

92 HR-HDA-890-BHZP, inv. br. 238.
} 
polaganje prisege kralju Petru i novim vlastodršcima u veljači te dvomjesečni boravak u prijestolnici Kraljevstva u ožujku i travnju 1919., ${ }^{93}$ vjerojatno radi pomaganja u transformaciji (u)pravnoga sustava nakon ujedinjenja te primanja instrukcija za daljnju službu. Valja naime imati na umu da je Kraljevstvo Srba, Hrvata i Slovenaca i u pravnome pogledu bilo prožeto partikularizmima te da se u njemu odjednom preklopilo šest dotad manje ili više zasebnih pravnih sustava: slovensko-dalmatinski, hrvatsko-slavonski, ugarski, bosanskohercegovački, srbijanski i crnogorski. ${ }^{94}$ Stoga ne treba čuditi da su novim vlastima bili potrebni „stari” stručnjaci, pa makar i oni koji su donedavno potkopavali okosnicu poslijeratne državne zajednice. Kako god bilo, Urbany je uspio uvjeriti poslodavce u odanost, pa je nešto manje od godinu dana nakon boravka u Beogradu, 21. veljače 1920., preuzeo ulogu kraljevskoga državnog odvjetnika od dr. Viktora Aleksandera, ${ }^{95}$ koji je krajem siječnja bio imenovan kraljevskim državnim nadodvjetnikom. Potonji je na dužnosti „starešine” zagrebačkoga državnog nadodvjetništva i umirovljen 1931. godine. ${ }^{96}$

Nedugo nakon imenovanja na spomenuto mjesto Urbany je morao pristupiti vojačenju kao pričuvni poručnik bivše austrougarske vojske. Krajem travnja 1920. proglašen je sposobnim za vojnu službu, ali je Komandi IV. armijske oblasti u Zagrebu iz ureda povjerenika za pravosuđe Kraljevske zemaljske vlade odaslana molba da ga se „riješi djelatne vojne službe [...] budući, da je na svom vrlo odgovornom i važnom mjestu neophodno potreban i nenadoknadiv", što je nekoliko mjeseci poslije ionako razriješeno inercijom sustava. Naime, odlukom ministra vojske i mornarice od 15. listopada 1920. izvan snage je stavljena njegova naredba s početka godine prema kojoj su pričuvni časnici (među kojima i Urbany) te drugi obveznici bili pozvani u vojnu službu. Iz dokumenata iz kojih su crpljeni prethodni podaci vidljivo je također da se Urbany prije zaprimljenoga poziva za mobilizaciju u precizno nenavedenom trenutku i osobno obratio Ministarstvu vojske i mornarice tražeći „prijem u vojsku kraljevstva Srba, Hrvata i Slovenaca”. Ta molba, na njegovu žalost ili sreću, do poziva na mobilizaciju nije bila „riješena”, pa se čitava situacija rasplela kako je opisano. ${ }^{97}$ Ako se smije nagađati, Urbany je prije dolaska na mjesto državnoga odvjetnika izveo manevar koji je držao potrebnim da mu se barem djelomično prizna prethodno služenje u austrougarskoj vojsci kako

93 HR-HDA-397-DN, Dosje Franjo Urbany, kut. 88.

94 KOSNICA, PROTEGA, „Politička prava u Kraljevini Srba, Hrvata i Slovenaca”, 145-146.

95 HR-HDA-397-DN, Dosje Franjo Urbany, kut. 88. O Viktoru Aleksanderu (1865. - 1934.), zamjeniku državnoga odvjetnika u Petrinji, Osijeku i Zagrebu te od 1920. do umirovljenja čelnoj osobi zagrebačkoga Kraljevskoga državnog nadodvjetništva, vidi više u: HR-HDA-397-DN, Dosje Viktor Aleksander, kut. 364 i MIRNIK, „Obitelj Alexander”, 96-126.

96 HR-HDA-397-DN, Dosje Viktor Aleksander, kut. 364.

97 HR-HDA-397-DN, Dosje Franjo Urbany, kut. 88. Vidi i: HR-HDA-81-ZVOP, inv. br. 407/1919. (Franjo Urbany) i HR-HDA-78-PRZV, 6-14, 11.386/1920. 
cijeli rok ne bi morao ponovno odslužiti u novoj državi, a možda (s obzirom na nedavnu profesionalnu prošlost - vjerojatnije) i zbog dodatnoga učvršćivanja povjerenja beogradskih centara moći u nj kao osobu koja će doskora preuzeti zvučne sudske i redarstvene dužnosti u hrvatskoj prijestolnici.

\section{„Prestupljenje protivu otečestva”}

O tome posredno svjedoči i njegovo profesionalno zalaganje na mjestu tužitelja u postupku protiv oporbenoga prvaka i negdašnjega suučesnika u spaljivanju mađarske zastave Stjepana Radića sredinom 1920. godine. Naime, dotadašnji državni odvjetnik, a poslije i nadodvjetnik V. Aleksander, svemu usprkos, nije pronalazio dovoljno dokaznoga materijala za pokretanje sudskoga postupka protiv Radića nakon njegova uhićenja po izravnome nalogu ministra unutarnjih poslova Svetozara Pribićevića i beogradskih centralističkih krugova krajem ožujka 1919. godine. ${ }^{98}$ Urbany je po sličnome nalogu sredinom 1920. postupio znatno drukčije od svojega prethodnika, djelomice i zato što je od samoga početka hajke na Radića, točnije od početka travnja 1919., bio u izravnoj vezi s čitavim postupkom preuzimajući uime Državnoga odvjetništva spise zaplijenjene premetačinom Radićeva stana u Međašnjoj 12. ${ }^{99}$ Možda je na temelju tih zasluga i imenovan državnim odvjetnikom godinu dana poslije.

Kako god bilo, Radić je nakon gotovo jednogodišnjega pritvora u veljači 1920. pušten na inicijativu bana Matka Laginje, na kojega je izravno utjecalo Aleksanderovo mišljenje o neutemeljenosti prikupljenih dokaza u postupku. Postoje mišljenja prema kojima je čitava akcija provedena bez blagoslova Beograda. ${ }^{100}$ To je izvjesno za Laginju, koji je s banske časti vrlo brzo smijenjen upravo zbog razmimoilaženja s vladajućima oko politike prema Radiću i Hrvatskoj pučkoj seljačkoj stranci (HPSS), ali za Aleksandera se to teško može sa sigurnošću reći budući da je do umirovljenja upravljao zagrebačkim državnim nadodvjetništvom, a 1922. zbog zasluga u službi dodijeljen mu je Orden Sv. Save III. reda te 1928. Orden Sv. Save II. reda. ${ }^{101}$

S druge je strane sasvim sigurno da je beogradski režim nakon Radićeva puštanja na slobodu samo tražio povod za njegovo ponovno utamničenje i pokretanje sudskoga postupka. Urbany se pokazao pogodnom osobom za to. Privođenje je bilo olakšano činjenicom da je čelnik HPSS-a odmah po izlasku iz zatočeništva nastavio s političkim djelovanjem. U veljači i ožujku održao je skupštine u Vrapču, Zagrebu i Galdovu kod Siska, koje su vladajućima poslu-

\footnotetext{
98 HR-HDA-78-PRZV, 6-14, 508/1919.; JANJATOVIĆ, „Državne uze, post i samica”, 99, 101.

99 Danas Ulica Dragutina Domjanića.

100 JANJATOVIĆ, „Državne uze, post i samica”, 99, 103.

101 HR-HDA-397-DN, Dosje Viktor Aleksander, kut. 364.
} 
žile da već 22. ožujka „bude uhapšen i predan sudu na postupak radi zločina protiv otečestva”, nakon čega je prebačen u zatvor Sudbenoga stola u Zagrebu. ${ }^{102}$

Optužnica protiv Radića na Sudbenom stolu u Zagrebu datirana je 2. lipnja 1920. godine. Bila je zasnovana na policijskim i izvještajima upravnih vlasti o njegovu političkom djelovanju od samih početaka nove državne tvorevine, kao i materijalima zaplijenjenim tijekom premetačine stana nakon uhićenja 1919. i 1920. godine. Državni odvjetnik Urbany, koji je vodio postupak optužbe, Radićevu je političku djelatnost okarakterizirao kao „prestupljenje protivu otečestva i vladatelja [...] zakona, vlasti i javnog poretka” te, kao takvu, kažnjivu po kaznenom zakonu. Vođa hrvatske oporbe u osam je točaka optužen zbog gledišta spram ujedinjenja Kraljevine Srbije i Crne Gore s Državom Slovenaca, Hrvata i Srba, nepriznavanja karađorđevićevske monarhije te zagovaranja saziva „hrvatske konstituante” s ciljem uspostave hrvatske seljačke republike unutar šire jugoslavenske federacije, uključujući i Bugarsku. ${ }^{103}$

$\mathrm{Na}$ kraju poprilično duge optužnice pisane na neobičnoj mješavini hrvatskoga i srpskoga jezika Urbany je, pozivajući se na sastanke i skupštine HPSS-a u Zagrebu, Vrapču i Galdovu tijekom veljače i ožujka 1920. te ostale zaplijenjene materijale i tiskovine, Radića optužio da stanovništvo

\begin{abstract}
„draži na nepokornost prema uredbama vlasti i djela koja su zakonom označena kao prestupljenje javno pravda i hvali te ujedno izlaže mrzosti i prezrenju javnim potvrdjivanjem izmišljenih i izopačenih stvari, te javnim oporočavanjem i ismejavanjem uredjenja državnih i zakonih naredjenja vlasti, te pobija njihovu važnost i podiže nepoverenje prema rečenim uredjenjima i naredjenjima, te konačno drži seljačtvo na mrzost i prezrenje protiv gradjanstva odnosno činovničtva, dakle jednu klasu žiteljstva protivu druge". ${ }^{104}$
\end{abstract}

Državni je tužitelj u optužnici, gotovo na osobnoj razini, Radiću posebno zamjerio napuštanje „legalne, parlamentarne borbe” za političke ciljeve, što ga je, prema njegovu sudu, i dovelo do toga da se „ogriješio o krivični zakon” i došao u sukob s „postojećim državno-pravnim poredkom”. ${ }^{105}$ Naposljetku su po toj optužnici Radiću dosuđene dvije i pol godine tamnovanja (ironično)

\footnotetext{
102 HR-HDA-78-PRZV, 6-14, 508/1919;; JANJATOVIĆ, „Državne uze, post i samica”, 104-107.

103 HR-DAZG-84-SSZ, 1063/1920., kut. 1262; JANJATOVIĆ, „Državne uze, post i samica”, 109110.

104 HR-DAZG-84-SSZ, 1063/1920., kut. 1262.

105 Isto; JANJATOVIĆ, „Državne uze, post i samica”, 111.
} 
pooštrenog ,jednim postom svakog I. decembra za vrijeme trajanja kazni” uz snošenje troškova kaznenoga postupka. ${ }^{106}$

Čini se također da su Urbanyjeve „pravnički formulirane” političke ocjene u tom postupku, usprkos drukčijim mišljenjima nadodvjetnika Aleksandera i bana Laginje, poslužile za stvaranje kasnijega općenitog stava centralističkih krugova spram Radića i njegove stranke. Pritom je osobito važan bio tužiteljev sud o utemeljenosti „privremenog ustava” Kraljevstva Srba, Hrvata i Slovenaca kao odgovor na Radićeve stavove da je država nastala 1. prosinca 1918. pravno neuređena te da nema ni ustav, ni izabrani parlament, ni vladara. Urbany je, za razliku od prvaka Hrvatske republikanske seljačke stranke (HRSS), držao da se privremeni ustav države zasniva na adresi Narodnoga vijeća i regentovu odgovoru na nj te da na istim temeljima počiva novostvorena državna zajednica. ${ }^{107}$ „Poslušniku karađorđevićevskog režima” to nije bio prvi pokušaj obrane pseudoustavnosti Kraljevstva Srba, Hrvata i Slovenaca i podilaženja centralističkom uređenju u povojima. Slične je stavove iznio i početkom svibnja 1920. u optužnici podignutoj pred Sudbenim stolom protiv Kamila Horvatina i devetnaest (novo)izabranih gradskih zastupnika Zagreba, pripadnika Socijalističke radničke partije Jugoslavije, koji su odbili položiti prisegu kralju Petru I. s obrazloženjem nepriznavanja Monarhije i traženjem izbora Konstituante. Urbany je tada stavove gradskih senatora okarakterizirao kao „izdajničko preduzeće [...] i učin zločinstva protivu vladatelja i otečestva”, nalazeći pravno uporište za takvu ocjenu među odredbama kaznenoga zakona Kraljevine Srbije protegnutog na čitavo područje Kraljevstva Srba, Hrvata i Slovenaca regentovim ukazom iz veljače 1919. godine. ${ }^{108}$ Usprkos optužnici, za razliku od Radićeva slučaja, do toga suđenja iz pobliže neznanih razloga nije došlo. ${ }^{109}$

\section{Ravnanje redom}

Urbanyjev su rad poslodavci ocijenili uspješnim. Omča oko vratova političkih neistomišljenika režima počela se stezati, a on je za nagradu 30. kolovoza 1921. odlukom Ministarskoga saveta Kraljevstva Srba, Hrvata i Slovenaca imenovan kraljevskim banskim savjetnikom, da bi mu „naredbom od 6. septembra 1921. bila povjerena uprava kr. redarstvenog ravnateljstva

\footnotetext{
106 „Osuda u Parnici protiv Radića”, Jutarnji list, 5. 8. 1920., 3-4.

107 HR-DAZG-84-SSZ, 1063/1920., kut. 1262; JANJATOVIĆ, „Državne uze, post i samica”, 112.

108 „Optužnica protiv bivših gr. zastupnika komunista”, Jutarnji list, 3. 8. 1920., 3-4; JANJATOVIĆ, „Državne uze, post i samica”, 112, bilj. 67.

109 Usp. JANJATOVIĆ, „Državne uze, post i samica”, 112, bilj. 67.
} 
u Zagrebu" ${ }^{110}$ Potonji događaji mogu upućivati na još jedno. Naime, ponovnim dolaskom S. Pribićevića na mjesto ministra unutarnjih poslova Urbany je iz djelokruga ministarstva pravosuđa imenovanjem za banskoga savjetnika prešao u domenu njegova novoga (starog) resora, a nedugo zatim preuzeo je i najvažniju policijsku dužnost u tadašnjoj Hrvatskoj. Bez naklonosti vođe hrvatskih Srba to vjerojatno ne bi uspio. Možda je Pribićević Urbanyju bio zaštitnikom i prilikom prvoga boravka na mjestu ministra unutarnjih poslova odmah po ujedinjenju, zbog čega je potonji nastavio napredovati u službi nove države iako je iz perspektive vlastodržaca itekako bilo razloga da ga se stavi u zapećak. Iz svega bi, ako je točno, slijedilo i da se Urbany priklonio politici Demokratske stranke, što mu je omogućilo i zaštitu i napredak u službi. $O$ svemu tome, dakako, može se samo nagađati jer su pouzdani dokazi zasad izvan našega dosega.

Urbanyju dolazak na čelo zagrebačkoga redarstva nije bio i prvi doticaj s redarstvenim poslovima. Djelokrug državnih odvjetnika i njihovih zamjenika, čini se, pored pravnih, nosio je sa sobom i izvjesne policijske osobine. Barem se tako da iščitati iz dokumentacije sačuvane o učestalim slučajevima paleža gospodarskih objekata u kotarevima Karlovac, Vrbovsko i Ogulin krajem 1911., kada je Predsjedništvo Zemaljske vlade tadašnjega zamjenika državnoga odvjetnika Urbanyja opunomoćilo za provođenje „redarstvenih predizvida”, podređujući mu u tom poslu „sve redarstvene oblasti u području rečenih sudbenih stolova”. Državni je odvjetnik naložene izvide doista i obavio, ali se čini da krivce za podmetanje požara nije pronašao. O tobožnjem dolasku „80 madjara u namjeri, da kuće pale”, kako se u to vrijeme moglo čuti među stanovništvom karlovačkoga kotara, naravno, nije moglo biti govora. Počinitelje je, izgleda, prije svega trebalo tražiti među lokalnim piromanima. ${ }^{111}$ Govoreći o Urbanyjevim prijašnjim doticajima s policijskim poslovima, ne smije se izgubiti iz vida i njegovo protuobavještajno djelovanje tijekom Prvoga svjetskog rata prožeto isljeđivanjem, premetačinama i istragama. Iskustva mu nikako nije nedostajalo.

Stoga ne čudi da je njegov dolazak na novu dužnost bio pun pogodak za vlastodršce. Uostalom, tamo ga bez razloga nisu ni namjestili. Urbanyjevo imenovanje na mjesto ravnatelja policije drugoga po veličini grada u državi samo mjesec dana nakon donošenja Zakona o zaštiti javne bezbednosti i poretka u državi nije moglo biti slučajno. Upravo je on bio odabran za provođenje represije nad komunistima i pripadnicima HRSS-a, ograničavanje slobode govora, javnoga okupljanja i drugih djelovanja stavljenih izvan zakona spo-

110 HR-HDA-81-ZVOP, inv. br. 407/1919. (Franjo Urbany). Usp. i: HR-HDA-890-BHZP, inv. br. 238.

111 HR-HDA-78-PRZV, 6-14, 4583/1911. 
menutim aktom. Za to se očito kvalificirao optužnicom protiv Radića. Pored toga, Urbany je prepoznat i kao pogodna osoba za (re)organizaciju zagrebačkoga redarstva po izravnim uputama iz jugoslavenske prijestolnice. Vjerojatno i zbog činjenice da je bio dobro upoznat $s$ historijatom i dotadašnjim načinom djelovanja zagrebačke policije. Uostalom, osobno je potpisao i jedan od rijetkih radova o toj temi u onodobnom tisku. U beogradskom (polu)službenom glasilu monarhističke policije u rujnu 1923. objavio je prilog pod naslovom „Zagrebačko redarstvo", ${ }^{112}$ u kojem je progovorio o preustroju policije hrvatske metropole. Taj je njegov članak postao izvjesnim polazištem za nekoliko naslova ove tematike koji su tiskani sljedećih godina, ${ }^{113}$ ali i okosnicom novijih spomena onodobnoga zagrebačkog redarstva. ${ }^{114}$

Prema Urbanyjevim riječima, zagrebačka je policija spadala u djelokrug poslova gradske općine do 1909., kada je ustrojeno Kraljevsko redarstveno povjereništvo kao državna institucija koja je u svoju nadležnost preuzela sve redarstvene agente iz dotadašnje općinske službe. ${ }^{115}$ No djelatnost toga povjereništva i dalje se protezala isključivo na područje gradske općine. Porast kriminaliteta, novo državno uređenje i s tim povezano protudržavno djelovanje dovelo je do potrebe ustrojavanja središnje redarstvene oblasti za čitavo područje Hrvatske i Slavonije. ${ }^{116}$ Uslijed toga, Naredbom o unutarnjem ustrojstvu Kraljevskog redarstvenog ravnateljstva u Zagrebu i kraljevskih redarstvenih povjereništava u Hrvatskoj i Slavoniji od 10. siječnja 1922. ${ }^{117}$ Redarstveno povjereništvo za grad Zagreb preoblikovano je u Kraljevsko redarstveno ravnateljstvo, čiji se djelokrug u predmetima zaštite države protegnuo na čitav teritorij Hrvatske i Slavonije. Ravnateljstvo je bilo ovlašteno djelovati i u „većim kriminalnim slučajevima, da ureduje neposredno sa svojim organima na cijelom tom teritoriju" ili preko nadležnih redarstvenih povjereništava i kotarskih oblasti. ${ }^{118}$ Sve su te promjene bile vrlo važne jer je njima Zemaljska vlada, odnosno zagrebačka Pokrajinska uprava, koja je također počela djelovati od 1922., izgubila redarstvene ovlasti nad kojima je dotad imala nadležnost,

\footnotetext{
112 URBANI, „Zagrebačko redarstvo”, 676-682.

113 Usp. VRAGOVIĆ, „Kratki prikaz razvoja redarstva u Zagrebu”, 671-675 te tekst istoga autora „Uvod. Kratki prikaz razvoja redarstva u Zagrebu”, 1-4.

114 Usp. MIKULAN, Povijest policije u Hrvatskoj, 260-268, 279-284.

115 Do početka 1909. zagrebačku policijsku upravu vodio je posebni redarstveni odsjek Gradskoga poglavarstva, a 15. siječnja te godine dužnost upravljanja policijom od gradske je općine preuzela autonomna zemaljska uprava. Konačno je banskom naredbom od 23. prosinca 1909. ustrojeno Kraljevsko redarstveno povjereništvo izravno podređeno Kraljevskoj zemaljskoj vladi (VRAGOVIĆ, „Kratki prikaz razvoja redarstva u Zagrebu”, 671).

116 URBANI, „Zagrebačko redarstvo”, 676-677.

117 Naredba od 10. januara 1922. Usp. i: „Naredba pokrajinskog namjesnika”.

118 URBANI, „Zagrebačko redarstvo”, 677-678.
} 
a u korist središnjega policijskog tijela pod izravnom kontrolom beogradske centrale policije.

Redarstveno ravnateljstvo bilo je ustrojeno u odsjeke, od kojih je najvažnije poslove obavljao „Predsjednički ured”. Njime je neposredno upravljao ravnatelj ravnateljstva, a osim funkcija vrhovne redarstvene uprave odsjek je obavljao i sve poslove povezane sa zaštitom države. Njegovi su uposlenici bili zaduženi za izdavanje dnevnih zapovijedi, personalije zaposlenika ravnateljstva, suradnju s oružništvom i vojništvom te poslove višega i političko-upravnoga redarstva. ${ }^{119}$ Već u prvoj godini djelovanja Predsjednički ured obradio je 17000 „poslovnih komada”. U političkoj evidenciji bilo je zabilježeno 5512 osoba, izdano je 9557 putovnica i 9615 viza. U Zagrebu je 1922. djelovalo 361 društveno udruženje pod redarstvenim nadzorom, od toga 132 prosvjetna, 67 sportskih i 112 strukovnih. U istom je razdoblju održano 19 „pouzdanih sastanaka”, 31 javni zbor, 124 javna predavanja i 11 konferencija. U glavnom je hrvatskom gradu u to vrijeme izlazilo 12 dnevnika, 47 tjednika te 104 polumjesečnika i mjesečnika, odnosno ukupno 163 časopisa koji su bili pod izravnim redarstvenim nadzorom. Nije naodmet spomenuti ni činjenicu da se u Zagreb samo te kalendarske godine doselilo ukupno 72810 stanovnika, od toga 16334 stranaca i 66476 „ovozemaca”. ${ }^{120}$

Sljedeći po važnosti bio je „Odsjek za kriminalno redarstvo”, u čiji je djelokrug spadala skrb o javnoj i privatnoj sigurnosti, nadzor nad otpuštenim kažnjenicima, osobama „pogibeljnim po sigurnost osobe i imetka” (izgnanicima, skitnicama, prostitutkama i svim osobama sumnjiva zanimanja) te vojnim bjeguncima, kao i postupci za suzbijanje kriminaliteta uopće (praćenje, vođenje kriminalnoga očevidnika te ureda za prepoznavanje, fotografiranje, daktiloskopiju, vođenje potraga za nestalima, nadzor nad uzištem Redarstvenoga ravnateljstva) te uređivanje „Redarstvenoga dnevnika” i vođenje kriminalnoga muzeja. ${ }^{121}$ Od srpnja 1922. do srpnja 1923. kriminalitet je usporedno s „brojem pučanstva i sa razvojem industrije i prometa [rastao] upravo rapidno”. U to je vrijeme u Zagrebu počinjeno 3427 zločina. Od toga su djelatnici toga odsjeka pronašli 1281 počinitelja, 912 uhitili, a ostali su pušteni na slobodu.

\footnotetext{
119 Među poslovima političko-upravnoga redarstva bili su nadzor nad javnim okupljanjima, nadzor tiskovina koje su spadale u redarstveni djelokrug, nadzor nad strancima, prijavništvo i nadzor nad Centralnim prijavnim uredom ravnateljstva, nadzor propisa o društvima, vjerski poslovi, putovnički, željezničarski i prometni predmeti, proizvodnja, prodaja i uporaba oružja, izdavanje „svjedodžbi ponašanja”, uredovanje o kršenju propisa u nadležnosti Predsjedničkoga ureda, dostavljanje podataka drugim odsjecima te uređivanje priručne knjižnice i zbirke normalija (Naredba od 10. januara 1922., 1-3; URBANI, „Zagrebačko redarstvo”, 677).

120 URBANI, „Zagrebačko redarstvo”, 677-678. Zbrojevi brojčanih podataka navedeni kod društava i doseljenika u Urbanijevu prilogu ne daju točan rezultat. Vjerojatno se radi o autorovu previdu.

${ }^{121} \quad$ Naredba od 10. januara 1922., 4-5.
} 
Sudski kažnjivih prijestupa i prekršaja u istome razdoblju bilo je 5105, a počinitelji su pronađeni u 3640 slučajeva, od kojih je 2843 privedeno. „Prekršaja što ih presuđuju policijske vlasti” počinjeno je 28470 . Od toga su pronađeni svi počinitelji, a uhićene su 242 osobe. Ukupna šteta počinjena krađama u tom razdoblju iznosila je oko 15.000 .000 dinara, od čega je pronađeno i oštećenima vraćeno $9.000 .000 .^{122}$

Treća ustrojstvena jedinica u sastavu Redarstvenoga ravnateljstva bio je „Odsjek za mjesno redarstvo”, na čijem se čelu nalazio „viši perovodni činovnik”, kojega je postavljao ravnatelj. U svojem je djelokrugu odsjek imao osiguravanje javnoga reda i mira na javnim mjestima gradskoga područja (trgovi, ulice, lokali, svratišta, kupališta), nadzor nad prometnim i cestovnim redarstvom, uredovanje nad „Vodenim pravom”, tržnim i živežnim redarstvom, putujućim obrtnicima, trgovcima i staretinarima, mjerama i cijenama, zatim suzbijanje nelegalne trgovine, podjelu dozvola za javne priredbe i igre, provođenje propisa o svetkovanju blagdana, plesnim, glazbenim i sličnim zabavama, uredovanje u slučajevima izgubljenih stvari, nadziranje nezgoda i elementarnih nepogoda, sudjelovanje u skrbi za djecu, suzbijanje alkoholizma, konkubinata, prostitucije te ostalih oblika nećudorednosti i $\mathrm{dr} .{ }^{123}$

„Zdravstveni odsjek” imao je zadatak nadzirati zdravstveno-redarstvenu službu, skrbiti se o zdravlju svih zaposlenika ravnateljstva te brinuti o stanju u uzištu, provoditi inicijative sanitarnih mjera na temelju vlastitih terenskih opažanja, obučavati redarstvene organe u nužnim i hitnim zdravstvenim slučajevima i voditi nabavku ljekarničkoga materijala za potrebe ravnateljstva. ${ }^{124}$ Na njegovu se čelu nalazio „kr. Redarstveni fizik”. ${ }^{25}$ U tom kontekstu Urbany je spominjao i „Ćudoredni odsjek”, koji je uz „saradnju redarstvenoga fizikata” nadzirao prostituciju u gradu. Sve su zagrebačke javne kuće naime u rujnu 1921. bile ukinute, a „tolerirala” se samo prostitucija „bez posredovanja poduzetnika”. Zbog toga je Redarstveno ravnateljstvo preuzelo posebnu zadaću zdravstvene brige o svim prostitutkama koje su se stavile pod redarstveni nadzor, a protiv ilegalne prostitucije borilo se „svim raspoloživim sredstvima najoštrije”. Sve evidentirane prostitutke bile su obvezne uplaćivati tjedni iznos u skrbnički fond iz kojega su se namirivali troškovi njihova liječenja te isplaćivala određena otpremnina „za slučaj povratka redovitom načinu života”. U djelokrug toga odsjeka još je spadala skrb o djeci i maloljetnicima. ${ }^{126} \mathrm{Iz}$ dostupnih podataka teško je razlučiti je li „Zdravstveni odsjek” spominjan u

122 URBANI, „Zagrebačko redarstvo”, 678-679.

123 Naredba od 10. januara 1922., 5-7. Usp. i: URBANI, „Zagrebačko redarstvo”, 679.

$124 \quad$ Naredba od 10. januara 1922., 8-9.

125 „Naredba pokrajinskog namjesnika”, 87.

126 URBANI, „Zagrebačko redarstvo”, 679-680. 
Naredbi bio istovjetan Urbanyjevu „Ćudorednom odsjeku”. Budući da se on nalazio na mjestu ravnatelja ravnateljstva i osobno ga je ustrojavao, vjerojatno se radilo o razlici između zakonodavne odrednice i onoga što je provedeno u praksi. Ruku na srce, za razdoblje 1919. - 1925. u drugim se vrelima u tom smislu doista spominju i ćudoredni i zdravstveni odsjek zagrebačkoga redarstva, ${ }^{127}$ pa je Urbany možda griješio u svojem iskazu ili je, vjerojatnije, smatrao da spominjanje „redarstvenoga fizikata” samo za sebe dovoljno govori o postojanju zasebnoga zdravstvenog odsjeka.

$\mathrm{Na}$ čelu „Zapovjedništva i zbora kr. redarstvene straže” nalazio se zapovjednik koji je u pravilu morao biti činovnik s „perovodnom kvalifikacijom”. Pod njegovu izravnu nadležnost spadali su „nadzornici kr. redarstvene straže” za pješadiju i konjicu, koji su nadzirali pravilno obavljanje dužnosti pripadnika redarstvene straže u službi i izvan nje te vodili brigu o njezinoj opskrbi. Sam zbor bio je sastavljen od „kontrolora kr. redarstvene straže”, koji su nadzirali i zapovijedali odjelima i postajama te dojavljivali nepravilnosti nadležnom nadzorniku „kr. redarstvenih nadstražara” što su služili pri odjelu Kraljevske redarstvene straže ili na stražarnicama redarstvenih kotareva, zapovijedajući manjim odjelima straže ili pojedinim stražarnicama. Na službu ih je dodjeljivao izravno zapovjednik straže. Redarstveni stražari obavljali su službu redarstvene straže kao pješaci ili konjanici. Konjica je pritom obavljala „ophodnu” službu, a „postajnu” samo na osobito prometnim mjestima. ${ }^{128}$

Šesti odsjek unutar Redarstvenoga ravnateljstva odnosio se na „Nadstojnika i zbor kr. redarstvenih detektiva”. Nadstojnik je morao biti najmanje u administrativnom razredu višega perovodnog činovnika, a postavljao ga je redarstveni ravnatelj, kojemu je bio izravno odgovoran. Nadstojnik je upravljao i vodio zbor, rukovodio službom, brinuo se o izobrazbi detektiva te ih dodjeljivao na rad pojedinim odsjecima i uredima Redarstvenoga ravnateljstva. Zbor redarstvenih detektiva sastojao se od nadzornika (koji je nadzirao detektive i skrbio se za valjano obavljanje službe, a bio je izravno podređen nadzorni$\mathrm{ku}$ ) te redarstvenih detektiva, koji su imali zadatak opažanja, upoznavanja i dojavljivanja svih događaja i okolnosti vezanih za održavanje javnoga reda i mira, nadzora osoba, mjesta i događaja, provođenja izvida i potraga po nalogu pretpostavljenih, nadzora provođenja propisa i zakona i prijave njihova narušavanja te privođenja, uhićenja i premetačina u skladu sa zakonima i propisima. Kraljevski redarstveni detektivi, kao i svi drugi pripadnici Redarstvenoga ravnateljstva, spadali su u red javnih namještenika, a bili su imenovani iz redova pripadnika Kraljevske redarstvene straže. ${ }^{129}$

127 ZORKO, „Ženska prostitucija u Zagrebu između 1899. i 1934. godine”, 234.

$128 \quad$ Naredba od 10. januara 1922., 9-12.

129 Isto, 12-15. 
U doba Urbanyjeva upravljanja policijom proračunskim sredstvima u Zagrebu je bilo osigurano 420 stražarskih mjesta, ali je od toga broja popunjena samo polovica. Stanje je donekle popravljeno dodjelom 50 vojnika koji su iz matičnih pukova pridruženi redarstvu. Međutim, oni zbog nedostatka izobrazbe u stražarskim poslovima nisu mogli biti upotrebljavani samostalno, nego pod izravnim nadzorom starijih i iskusnijih stražara. U Zagrebu je trebalo biti uspostavljeno i 8 „stajaćih” i 54 „rajonske” stražarske postaje, ali ih je uistinu djelovalo samo 8 stajaćih i 10 rajonskih. Osim tih pješačkih, redarstvo je u svojem sastavu imalo i 4 konjičke postaje te 3 konjičke patrole na gradskoj periferiji. Zbor redarstvenih detektiva imao je 70 detektiva, „odgovarajući broj” nadzornika te nadstojnika. Urbany je držao da je zagrebačko redarstveno ravnateljstvo u prvoj godini nakon preustroja brojem ljudi i opremljenošću bilo nedostatno za održavanje javnoga reda i mira u gradu koji je u to vrijeme imao oko 120000 stanovnika. ${ }^{130}$

Naredbom iz siječnja 1922. bilo je propisano i ustrojavanje „Centralnog prijavnog ureda” kao zasebne jedinice sa zadatkom vođenja „cjelokupne prijavne očevidnosti za grad Zagreb” te izdavanje uredovnih potvrda na temelju spomenutih evidencija. Na čelu toga odsjeka nalazio se perovodni činovnik kojega je postavljao ravnatelj Redarstvenoga ravnateljstva. ${ }^{131} \mathrm{Za}$ Centralni prijavni ured Urbany je zabilježio da se u njemu vodila „evidencija pučanstva u formi kartoteka" tako da su se zasebno vodili očevidnici za trenutačno nastanjene stanovnike grada, bivše (iseljene ili preminule) žitelje, strance (strani državljani u prolazu i stalno naseljeni u gradu), očevidnik osoba traženih od redarstva po bilo kojoj osnovi te očevidnik „poslovnih nastana”, odnosno registriranih sjedišta poslovanja gospodarskih subjekata. U djelokrug prijavnoga ureda, prema riječima tadašnjega ravnatelja, spadao je i kazneno-redarstveni postupak zbog prekršaja prijavnih propisa, a sam prijavni ured bio je uređen po uzoru na bečki i berlinski, pa je i svaka redarstvena stražarnica imala vlastitu „prijavnu ekspozituru” radi olakšavanja pristupa strankama. Uz kotarske ispostave ravnateljstva nalazile su se i njihove samostalne prijavne ispostave, koje su vodile posebne očevidnike za svoje područje. ${ }^{132}$

„Uzište kr. redarstvenog ravnateljstva” kao samostalni odsjek bilo je sastavljeno od dijela predviđenog za uhićenike višega državnog redarstva, za uhićenike kriminalnoga redarstva, osuđene za prekršaje redarstvenih propisa te mladež i prepraćene osobe. Nadzor nad poslovima i redom uzišta vodio je „kr. redarstveni uzničar”, koji je bio neposredno podčinjen šefu Odsjeka za

\footnotetext{
130 URBANI, „Zagrebačko redarstvo”, 680-681.

$131 \quad$ Naredba od 10. januara 1922., 15.

132 URBANI, „Zagrebačko redarstvo”, 680.
} 
kriminalno redarstvo. ${ }^{133}$ Prema Urbanyjevim riječima, od 1. srpnja 1922. do 1. srpnja 1923. u Zagrebu je uhićeno i u zatvor Redarstvenoga ravnateljstva privedeno ukupno 15586 osoba. Od toga je redarstveno presuđeno 5360 osoba, državnom tužitelju predane su 1052, kotarskom sudu 1084, a sudu za mladež 112 osoba. U istom je razdoblju „u zavičaj” prognano 2357 , komandi mjesta proslijeđeno 119, a na prisilno bolničko liječenje 343 osobe. ${ }^{134}$

Redarstveno ravnateljstvo imalo je i odsjek „Pomoćnih ureda”, na čijem je čelu stajao viši manipulativni činovnik neposredno podčinjen ravnatelju. U djelokrug pomoćnih ureda spadalo je vođenje cjelokupne pisarničke aktivnosti te s njom povezanih novčanih transakcija. Pomoćne su urede činili urudžbeni zapisnik, prijepisni ured, otpravništvo i pismara. ${ }^{135}$

Posljednji, deseti odsjek bio je „Ekonomat kr. redarstvenoga ravnateljstva”, u čiji je djelokrug spadalo financijsko poslovanje ravnateljstva, osobito u pitanjima proračuna, nadzora nad unutarnjim gospodarenjem, isplate plaća i svih ostalih troškova vezanih za osoblje. Na čelu ekonomata nalazio se viši računarski ili manipulativni činovnik, neposredno podređen redarstvenom ravnatelju. ${ }^{136}$

U svojem je elaboratu Urbany naveo i da je onodobno zagrebačko redarstveno područje bilo razdijeljeno na četiri kotara, u kojima su bile uređene kotarske ispostave Redarstvenoga ravnateljstva. Na njihovu su čelu stajali činovnici s fakultetskom spremom, a unutar svakoga kotara nalazila se jedna ili više redarstvenih stražarnica ili stražarskih ispostava. Ukupno je djelovalo 11 stražarnica i stražarskih ispostava. U zagrebačkom je redarstvu tada bilo zaposleno 29 redovnih činovnika s fakultetskom spremom, 2 liječnika, 15 manipulativnih činovnika, 20 „oficira straže” i nadzornika detektiva, 32 nadstražara, 70 detektiva, 236 stražara i 72 dnevničara, sluga pomagača, kuhara i dr. Kao nasušnu potrebu „za dignuće redarstva u Zagrebu i za osiguranje javne bezbednosti" ravnatelj je prepoznao povećanje plaća redarstvenim stražarima, bez čega se nije mogao kompletirati njihov propisani broj i bez kojih je čitav dobro odrađen administrativni posao bio manjkavo i nedostatno proveden na terenu. ${ }^{137}$

Malo je sumnje da Urbany nije bio osobno zaslužan za reorganizaciju zagrebačke policije u opisanim okvirima. Uostalom, to su mu priznavali i njegovi suradnici, ali i beogradske policijske vlasti. Tako je jedan od vodećih onodobnih zagrebačkih redarstveno-pravnih stručnjaka Aleksa Vragović pribilježio:

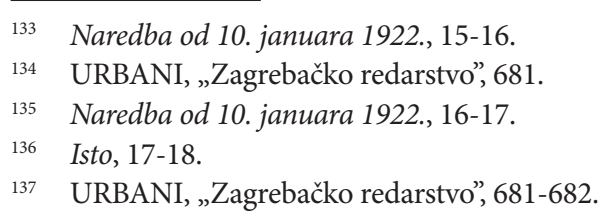




\begin{abstract}
„Osnutkom kr. Redarstvenog ravnateljstva u Zagrebu učinjen je i prvi korak za sistematsku izgradnju unutarnje organizacije redarstva u Zagrebu. Iz ovde obelodanjenih propisa i statuta najjasnije se vidi, što je na polju organizacije redarstva u Zagrebu u ovo kratko vreme učinjeno. Najveća zasluga za ovaj rad ide prvoga ravnatelja redarstva u Zagrebu g. Franju Urbania, od koga je sveđer poticala nova inicijativa kako za rad na poboljšanju postojeće organizacije, tako i za stvaranje novih institucija u krilu redarstvene direkcije, a u svrhu unapređenja redarstvene službe."138
\end{abstract}

Urbany je bio zaslužan i za organiziranje policijske konferencije u studenome 1923. u Zagrebu, odobrene i poduprte od nadležnoga ministarstva. Na njoj su delegati iz raznih područja države raspravljali o međunarodnoj suradnji na razini europskih policijskih uprava te gorućim poteškoćama u struci, od evidencije i kontrole dolaska stranaca, izdavanja putovnica, praćenja i evidentiranja sumnjivih osoba, kontrole djelatnosti radničkih sindikata i tiska do reguliranja automobilskoga prometa. ${ }^{139}$ Nakon održanoga događanja načelnik u Ministarstvu unutarnjih dela Vasa Lazarević naglasio je u izvještaju ministru da su svi delegati koji su pribivali konferenciji bili „prijatno iznenađeni stručnim, savesnim i savršenim uređenjem Zagrebačke policije koja može da posluži kao primer do kakvog rezultata i savršenstva može da dovede smišljen organizatorski rad". ${ }^{140}$

Urbany nije bezrazložno ubirao lovorike naporna i predana rada u (re) organizaciji zagrebačkoga redarstva. Za njegova se upravljanja, osim zavidnih brojki u rješavanju temeljnih policijskih poslova, vodila briga i o drugim, naizgled manje važnim sastavnicama profesionalnoga djelovanja. Tako je unutar redarstva bio organiziran orkestar limene glazbe sastavljen od 36 redarstvenika, a zasluge za nabavku instrumenata i svesrdnu potporu organiziranju zbora išle su izravno ravnatelju. ${ }^{141}$ Takvo gotovo osobno povezivanje djelatnika unutar (represivne) institucije bilo je više nego poželjno u vremenima koja su zahtijevala usku, ne samo službenu, suradnju redarstvenih kadrova. U tom se kontekstu može promatrati i utemeljenje „Policijskoga sportskoga kluba”, koji je već u prvoj godini osnutka pobirao uspjehe u „viteškim utakmicama” organiziranim s vojnicima i podoficirima zagrebačke podoficirske škole te predstavnicima svih pješadijskih i artiljerijskih pukova smještenih u hrvatskom glavnom gradu. ${ }^{142}$

138 VRAGOVIĆ, „Kratki prikaz razvoja redarstva u Zagrebu”, 673.

139 „Policijska konferencija”, 869-870; „Zaključci doneti na policijskom kongresu u Zagrebu”, 914-916.

140 VRAGOVIĆ, „Kratki prikaz razvoja redarstva u Zagrebu”, 673.

${ }_{141}$ „Novine u zagrebačkoj policiji”, 393-394.

142 Isto, 394. 
Nije naodmet spomenuti i da je za Urbanyjeva ravnanja u izdanju zagrebačkoga Kraljevskoga redarstvenog ravnateljstva bila tiskana Zbirka propisa o organizaciji redarstva u Zagrebu, ${ }^{143}$ u kojoj su sabrani „organizatorski propisi” vezani za ustrojstvo zagrebačkoga redarstva. Njezino je objavljivanje trebalo ispuniti dvije svrhe: biti priručnikom organima zagrebačkoga redarstva u svakodnevnome radu te poslužiti „drugim redarstvenim vlastima u zemlji kod izgradnje njihove vlastite organizacije”. Pozitivno iskustvo u preustroju zagrebačkoga redarstva trebalo je dakle poslužiti kao svojevrsni ogledni obrazac za modernizaciju ustrojstva ostalih glavnih policijskih ispostava Kraljevstva. ${ }^{144}$ To za trajanja stare jugoslavenske države usprkos prijedlozimaa ${ }^{145}$ nije učinjeno.

\section{Mirnije vode}

I pored svih uspjeha Urbany se nije duže zadržao na mjestu upravitelja zagrebačke policije. Vremena su zahtijevala čvršću ruku, a Franjo ju, čini se, nije ponudio. ${ }^{146}$ Beogradski su centri moći za planirane poteze prema političkim neistomišljenicima u Hrvatskoj tražili osobu drukčijega karaktera. Iz sačuvanih se vrela s oprezom može zaključiti da je Urbany bio primoran podnijeti ostavku. Naime, Aleksandrov ukaz o njegovu premještanju „po potrebi službe od kr. redarstvenog ravnateljstva u Zagrebu pokrajinskoj upravi, odelenju za unutarnje poslove u Zagrebu" nosio je datum 9. studenog 1924. godine. Franjina molba za razrješenje s mjesta dužnosti ravnatelja redarstva upućena Predsjedništvu Pokrajinske uprave za Hrvatsku i Slavoniju u Zagrebu datirana je 10. studenog iste godine. Da je Urbany gotovo sigurno znao za skorašnju smjenu, svjedoči molba za desetodnevni godišnji odmor odobrena 1. studenog, nakon čijega je isteka i uslijedio zahtjev za razrješenje s mjesta ravnatelja policije. Istoga dana kada je potpisao molbu za razrješenje zatražio je i dodatni tridesetodnevni odmor, koji je trebao nastupiti „nakon predaje moje dužnosti ravnatelja redarstva”. ${ }^{147} \mathrm{Na}$ temelju toga može biti malo sumnje da sve nije bilo unaprijed isplanirano, i Franjin odlazak i dolazak novoga ravnatelja. Jedino što su u čitavoj predstavi poslodavci uranili s izdavanjem dekreta, a Urbany zakasnio s molbom za razrješenje, koju je obrazložio prilično upečatljivim riječima:

\footnotetext{
143 Zbirka propisa o organizaciji redarstva.

144 VRAGOVIĆ, „Uvod. Kratki prikaz razvoja redarstva u Zagrebu”, 1-4.

145 Usp. VRAGOVIĆ, „Reorganizacija naše policije”, 585-593.

146 Usp. navod o Urbanyjevu uvjeravanju nadređenih da Radić pod prijetnjom novoga uhićenja krajem srpnja i početkom kolovoza 1923. neće napustiti državu, nego će se skrivati u onim krajevima koji su „skroz u njegovim rukama”. Redarstveni izvidi na kojima je temeljio zaključke iznesene $\mathrm{u}$ izvještaju pokrajinskome namjesniku pokazali su se potpuno netočnima jer se vođa oporbe $u$ vrijeme sastavljanja izvještaja već nalazio u inozemstvu (KRIZMAN, Korespondencija Stjepana Radića, 87).

147 HR-HDA-890-BHZP, inv. br. 238.
} 
„Ne ćutim se zdravstveno dosta jakim, da bi mogao bez uštrba za interese službe i dalje vršiti dužnosti skopčane sa mojim položajem." ${ }^{148}$ Čini se da je zbog mogućega „uštrba” službi u danima koji su uslijedili i morao zatražiti razrješenje. Poznato je naime tko ga je i zbog čega zamijenio. Istoga dana (!) kada je Urbany zatražio odlazak s dotadašnjega položaja, iz Požege je s mjesta upravitelja tamošnje kotarske oblasti u Zagreb na mjesto upravitelja Kraljevskoga redarstvenog ravnateljstva premješten zloglasni dr. Janko Bedeković. Već dan poslije preuzeo je dužnost. ${ }^{149}$ Vrijeme će pokazati s kojim zahtjevima. ${ }^{150}$

Da je izgubio povjerenje vlastodržaca, zbog čega je na kraju i smijenjen, svjedoči i činjenica da nadležno ministarstvo nakon 1924. Urbanyju više nije dopuštalo sudjelovanje u međunarodnim policijskim tijelima. On je naime s Aleksom Vragovićem na međunarodnom policijskom kongresu u Beču 1923. bio izabran u ,internacionalnu kriminalno policajnu komisiju”, ${ }^{151}$ koja je imala zadatak povezivanja europskih policija radi bržega protoka informacija o pripadnicima kriminalnoga miljea. Usprkos molbama, na kongrese 1926. u Berlinu i 1927. u Amsterdamu bio je poslan samo Vragović, koji za razliku od Urbanyja, usput rečeno, kao tajnik zagrebačkoga Kraljevskoga stola sedmorice više nije bio izravno povezan s policijskim poslovima. Tu, dakako, valja imati na umu i posvemašnju paranoju onodobnih beogradskih (policijskih) vlasti od razmjene bilo kakvih informacija s europskim policijama i odbojnost spram takva vida razmjene podataka zbog prikrivanja vlastitoga terora prema političkim neistomišljenicima. ${ }^{152}$ Smijenjeni redarstveni ravnatelj, čini se, više nije ulijevao povjerenje za obavljanje za državu osjetljivih poslova.

Kako god bilo, Urbany se na novom radnome mjestu zadržao nepunih pola godine. Kao banski savjetnik treće grupe prve kategorije, vladarevim ukazom od 8. travnja 1925. dodijeljen je velikom županu Zagrebačke oblasti. Ondje je krajem dvadesetih godina XX. stoljeća obnašao dužnost šefa redarstvenoga odjeljenja i zamjenika velikoga župana. U to je doba bio i predsjednik „oblasne Komisije za ocjenu državnih službenika kod oblasti zagrebačke”, ${ }^{153}$ a na samom kraju 1929. imenovan je i disciplinskim sucem I. kategorije Disciplinskoga suda pri banu Savske banovine, namijenjenog provođenju postu-

\footnotetext{
148 Isto.

149 HR-HDA-890-BHZP, inv. br. 1258.

150 Više o upravitelju zagrebačke policije u dva navrata „koji je u društvenu zbilju Zagreba i Hrvatske urezao duboku traumu, postavši sinonimom policijske bestijalnosti starojugoslavenskoga režima prema najširim slojevima stanovništva” vidi u: STIPANČEVIĆ, „Vampir iz Petrinjske”, 104128; STIPANČEVIĆ, „Mlada Jugoslavija”, 127-155 (navod u bilješci sa str. 128); STIPANČEVIĆ, „U obrani ‘̌uftova i dreka”, 215-227.

151 HR-HDA-1363, Politička situacija (Grupa XXI), inv. br. 1217.

152 Isto.

153 HR-HDA-890-BHZP, inv. br. 238.
} 
paka protiv povrede službenih dužnosti za činovnike spomenutoga upravnog područja. ${ }^{154}$

Pred smiraj profesionalne karijere našao se u situaciji koja ga je vrlo vjerojatno nagnala na prijevremeno i neplanirano umirovljenje. Iako je krajem 1930. bio odlikovan pobliže nepoznatim vladarevim odlikovanjem, početkom 1931. naređeno mu je preuzimanje dužnosti banskoga inspektora pri banskoj upravi u Nišu. ${ }^{155}$ Nije posve jasno zašto je trebalo doći do premještaja na drugi kraj države, ali se to teško moglo smatrati nagradom. Barem se tako da iščitati iz posljedičnih zbivanja, prema kojima se Urbany premještaju nije povinovao, vjerojatno ne želeći napuštati grad u kojem je proveo čitav radni vijek i dotadašnji život. Odmah je zatražio bolovanje, a liječnička komisija Odjeljenja za socijalnu politiku i narodno zdravlje Kraljevske banske uprave u Zagrebu posljednjega dana siječnja 1931. odredila mu je tromjesečno kućno liječenje. No organi Kraljevske banske uprave Moravske banovine iz Niša tu nisu stali. Nakon isteka bolovanja inzistirali su na Urbanyjevu dolasku na novo radno mjesto. To se nije dogodilo jer mu je liječenje produženo za sljedeća tri mjeseca, do 21. lipnja, a nakon toga i za novih trideset dana. Liječničko-pravno-administrativna zbrka na kraju je razriješena Urbanyjevim umirovljenjem 20. srpnja 1931., nakon što mu je u godine službovanja bilo uračunato „razdoblje vojne službe [...] prosluženo u pređašnjoj austro-ugarskoj vojsci od 27-VII1914. god. do 29-X-1918. god."156

Poradi potpune dosljednosti na ovome mjestu ipak valja reći da iznenadni premještaji istaknutih činovnika u neku drugu banovinu, s kakvim se svojevremeno suočio i Urbany, nisu bili posve rijetki. Možda su ga, suprotno prethodnome mišljenju, vlasti baš htjele vidjeti u Nišu kao uglednijega, višerangiranoga, organiziranijega i dokazanoga činovnika. Pogotovo ako se zna da je tada u Srbiji manjkalo službenika s akademskom naobrazbom. Najzad, u siječnju 1931. dogodile su se i promjene u upravnom aparatu Savske banovine kada je dotadašnjega bana dr. Josipa Šilovića zamijenio dr. Ivo Perović, pa možda i u tom događaju treba tražiti uzroke Urbanyjeva premještaja, koji je on, nema sumnje, razumijevao kao kaznu.

\footnotetext{
154 HR-HDA-143-SBOO, V.D.S. br. 3-72, kut. 101.

155 HR-HDA-890-BHZP, inv. br. 238.

156 Isto.
} 


\section{Gajeva 51}

Nažalost, o Urbanyjevu privatnom životu zna se vrlo malo. Izravnih potomaka nije imao. ${ }^{157}$ Tridesetoga travnja 1916. u zagrebačkoj crkvi sv. Marka oženio se Bertom Marijom Poznovia, kćerkom Bogoljuba i Terezije rođ. Dvoŕak, rođenom 9. travnja 1888. godine. Na vjenčanju su im kumovali Janko Holjac, „načelnik grada Zagreba”, i Milutin Urbany, „profesor kr. višeg gospodarskog učilišta”. U trenutku sklapanja braka oboje mladenaca živjelo je u Gundulićevoj ulici: Franjo na br. 48, a Berta Marija nekoliko kuća niže, na br. $37 .{ }^{158}$ Ondje su se vjerojatno upoznali i zaljubili. Četrnaest godina dobne razlike očito se nije pokazalo preprekom.

Nema sumnje da je Urbany bio dobro uključen u život viših slojeva onodobnoga zagrebačkoga društvenog života. Uostalom, potjecao je iz ugledne obitelji, a i sam je obavljao više nego zvučne društvene dužnosti. U gradu od stotinjak tisuća stanovnika i s vrlo tankim intelektualnim slojem nije mogao ostati nezamijećen. Da je tomu moglo biti tako, svjedoči i rijedak spomen njegovih društvenih kontakata iz razdoblja ravnanja zagrebačkom policijom. Urbany je naime bio u prijateljskim odnosima s uglednim veleindustrijalcem, dobrotvorom te počasnim portugalskim konzulom u Zagrebu Aleksandrom Ehrmannom, jednom od najvažnijih osoba tadašnje drvne industrije u nas te rado viđenim sudionikom brojnih javnih događanja. Upravo se u njegovu društvu Urbany od 10. do 22. svibnja 1923. otisnuo na krstarenje u organizaciji „Društva za promet stranaca” na parobrodu Salona „Jadranske plovidbe” od Bakra do Bara i natrag. Na krstarenju se našlo 58 uglednika, ponajviše industrijalaca, te čak sedam konzula. Organizator putovanja bio je rumunjski konzul Milan Milić, ujedno i predsjednik društva koje je organiziralo krstarenje. ${ }^{159}$ Opravdano je pretpostaviti da ravnatelj policije na dvotjedno putovanje nije bio pozvan isključivo zbog prijateljstva s Ehrmannom.

Urbanyjevi su najmanje od posljednjega desetljeća XIX. stoljeća bili nastanjeni u zagrebačkoj Gundulićevoj ulici. Onamo su se preselili između rođenja Franjina brata Marijana 1886., kada je obitelj živjela u Savskoj ulici 7, ${ }^{160}$

\footnotetext{
157 Prema saznanjima autora, jedini živući član obitelji Urbany u Hrvatskoj sa suprugom živi u Splitu na adresi Table XIII. Franjin je neizravni potomak preko njegova brata Marijana, poginulog u Prvom svjetskom ratu. Kako je rečeno, tom se carskom i kraljevskom poručniku i gimnazijskom profesoru posmrtno rodio istoimeni sin, poslije sveučilišni profesor i otac Marijana $\left({ }^{\star} 1942\right.$.) iz Splita. Dobrotom potonjega i njegove supruge, kojima dugujem zahvalnost, uz ovaj će prilog biti objavljene i Franjine slike. „Onkel Franc” je naime bio Marijanov krsni kum, pa su se njegove fotografije do danas sačuvale u obiteljskom albumu.

158 HR-HDA-1448-ZBMK, ZM-34C/665, Zagreb, župa sv. Marko, MKV 1912.-1918.

159 FAK, „Aleksandar Ehrmann (1879-1965)”, 326-345.

160 HR-HDA-1448-ZBMK, ZM-34C/1198, Zagreb, župa sv. Marko, MKR 1882.-1888.
} 
i očeve smrti 1900., kada je za adresu bila navedena Gundulićeva $14 .{ }^{161}$ Majka i brat Kamilo preminuli su 1920. na adresi Gundulićeva $48 .^{162} \mathrm{Na}$ toj je adresi stanovao i Franjo do vjenčanja, kako je spomenuto. Nije poznato kada se točno odselio, ali nije otišao daleko. Sa suprugom se nastanio u prizemlju kuće u Gajevoj ulici 51 i ondje ostao do kraja života. U kući nasuprot stanovao je brat Milutin sa suprugom. Od umirovljenja do smrti Franjo je živio mirnim i povučenim životom, koji su, kao i ostalim žiteljima, prekinule ratne godine. ${ }^{163}$ Ako je suditi po fotografijama sačuvanim u obiteljskom fotoalbumu, i rat i poraće protekli su u relativnoj sigurnosti. U drugim dostupnim vrelima također nema podataka da je imao poteškoća bilo s endehazijskim, bilo s komunističkim režimom. Negdašnji ravnatelj Redarstvenoga ravnateljstva preminuo je 20. siječnja $1951 .{ }^{164}$ Supruga ga je nadživjela punih 29 godina. ${ }^{165}$

\section{Ključanice života}

Sudeći prema rečenom, život Franje Urbanyja pokazivao je slične profesionalne značajke kao i životi drugih međuratnih upravitelja zagrebačke policije poznatijih biografija, poput Josipa Vragovića i Janka Bedekovića. I on je morao promijeniti ideološki kaput da bi opstao u represivnom aparatu više državnih tvorevina. To možda i nije bila stvar osobnosti. Vremena su bila zlosretna i tražila su vratolomne zaokrete.

Urbany je rođen u dobrostojećoj i uglednoj zagrebačkoj obitelji, koja mu je omogućila donekle utrt put $\mathrm{k}$ uspjehu u pravosudnim strukturama onodobnoga Zagreba i Hrvatske. Mladenačka nepromišljenost i sudjelovanje u protumađarskim demonstracijama 1895. zamalo ga je stajalo karijere. Da je nastavio tim putom, možda bi mu život bio uokviren sličnim obilježjima kao i onima koje je po nastanku nove zajednice i u njezino ime kao državni odvjetnik progonio. Analizirajući optužnice protiv Radića i komunističkih zastupnika u zagrebačkoj skupštini, može se pomisliti da je (tada) bio oduševljen jugoslavenskim državnim jedinstvom i od Beograda skrajanim centralističkim uređenjem Kraljevstva. Da nije bilo tako, teško bi se zdušno prihvatio progona političkih neprijatelja režima kada su se drugi (pa i njemu izravno nadređeni)

\footnotetext{
161 HR-HDA-1448-ZBMK, ZM-34/341, Zagreb, župa sv. Marko, MKU 1897.-1900.

162 HR-HDA-1448-ZBMK, ZM-34C/670, Zagreb, župa sv. Marko, MKU 1918.-1924.

163 Prema kazivanju g. Marijana Urbanyja autoru priloga u njegovu stanu u Splitu 21. veljače 2020. godine. Nažalost, kazivač se nije prisjećao mnogo detalja iz Urbanyjeva života, osim da je „strica kuma Franju” i „tetu kumu Mimicu” posjećivao u njihovu stanu i s njima često šetao Sljemenom.

164 HR-HDA-1448-ZBMK, ZM-34C/98, Zagreb, župa sv. Marko, MKR 1866.-1878.

165 Gradska groblja (2).
} 
tomu opirali, a kasnije i ravnanja i uređivanja zagrebačke, umnogome i hrvatske policije.

I u jednom i u drugom Urbany je bio uspješan. Radić je na temelju njegove optužnice kažnjen višegodišnjim strogim zatvorom, a rečenice državnoga odvjetnika izrečene u obranu ustavnosti nove državne zajednice dugo su zvonile u ušima političkih neistomišljenika i oporbe. Za pogrešne se stavove plaćalo slobodom, nerijetko i životom. Zagrebačko redarstveno ravnateljstvo preuredio je po uzusima modernih zapadnoeuropskih praksi ugledajući se u bečku i berlinsku policiju. Dakako, shodno dostupnim financijskim sredstvima i zadanom političkom okviru. Gotovo je nevjerojatno da je samo u jednoj godini njegova ravnateljevanja kroz zagrebačke redarstvene tamnice prošlo 15600 osoba, odnosno oko 13 \% ukupnoga stanovništva glavnoga hrvatskoga grada. ${ }^{166}$ Ako se i uzme da su neki od uhićenih, poput „ilegalnih” prostitutki i skitnica, vjerojatno privođeni i po nekoliko puta - brojke su visoke. Opravdano je pomisliti da je nemali dio stradavao i iz političkih razloga. Urbany je bio sposoban upravitelj i zbog toga nisu manjkale ni pohvale odaslane iz beogradskih centara moći.

Zbog čega je onda smijenjen i krajem 1924. gurnut u administrativno-redarstveni zapećak, daleko od izravnoga utjecaja na društvena zbivanja? Odgovor možda i nije teško naslutiti iz događaja koji su uslijedili. Urbany je izgubio povjerenje poslodavaca. Kada mu je to bilo naređeno, nije mogao, umio ili (najmanje vjerojatno) htio učiniti ono što je vrlo brzo i s velikom predanošću učinio njegov nasljednik na čelu redarstva Bedeković - nemilosrdnim nasiljem slamati protudržavne neprijatelje u vidu političke oporbe, otpočevši s „izvlačenjem Radića iz rupe".

166 Prema: URBANI, „Zagrebačko redarstvo”, 680-681. 


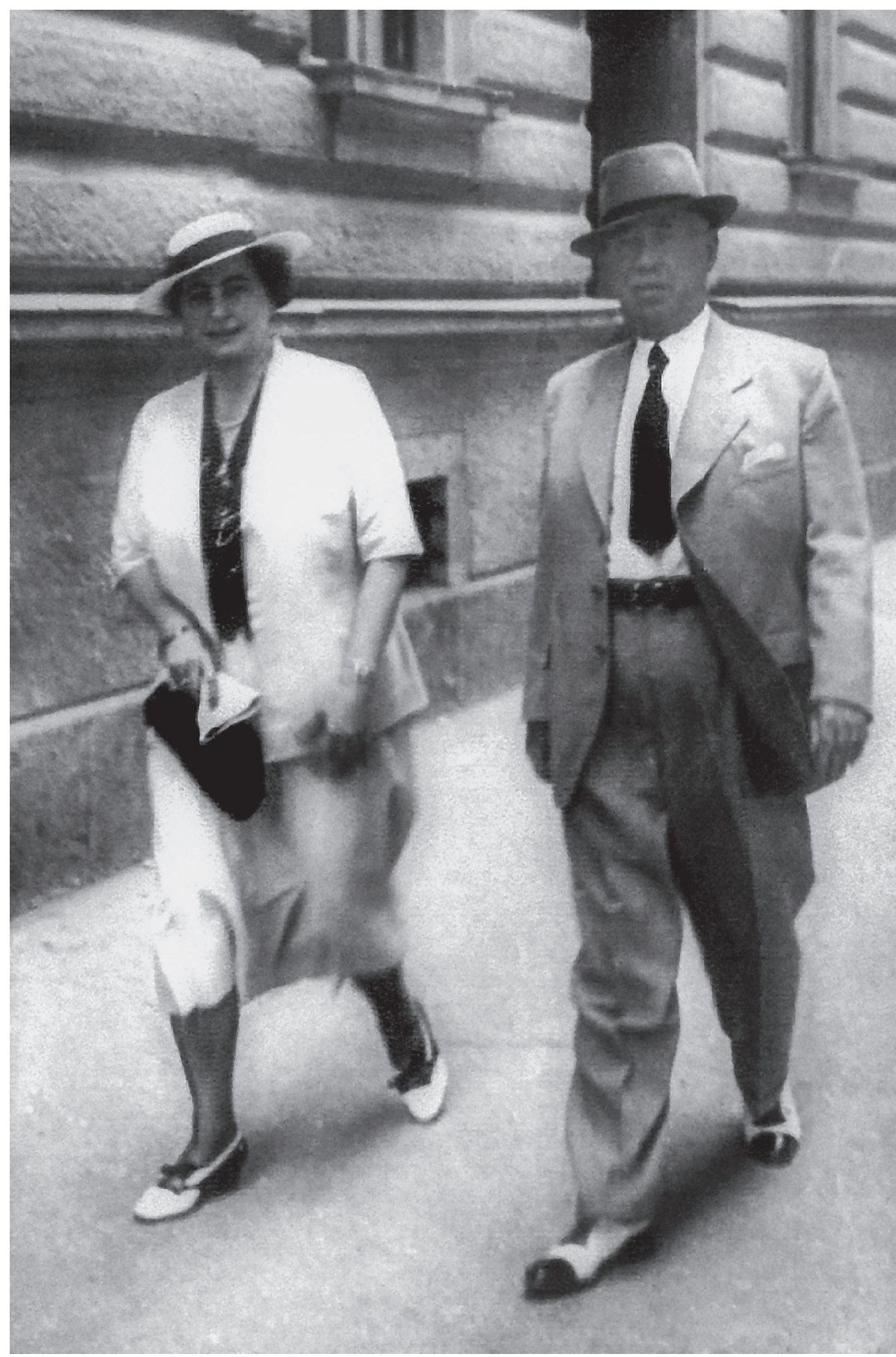

Slika 1. Franjo Urbany sa suprugom Bertom Marijom u šetnji zagrebačkom ulicom Pavla Hatza, 3. kolovoza 1939. (Obiteljski fotoalbum Marijana Urbanyja) 


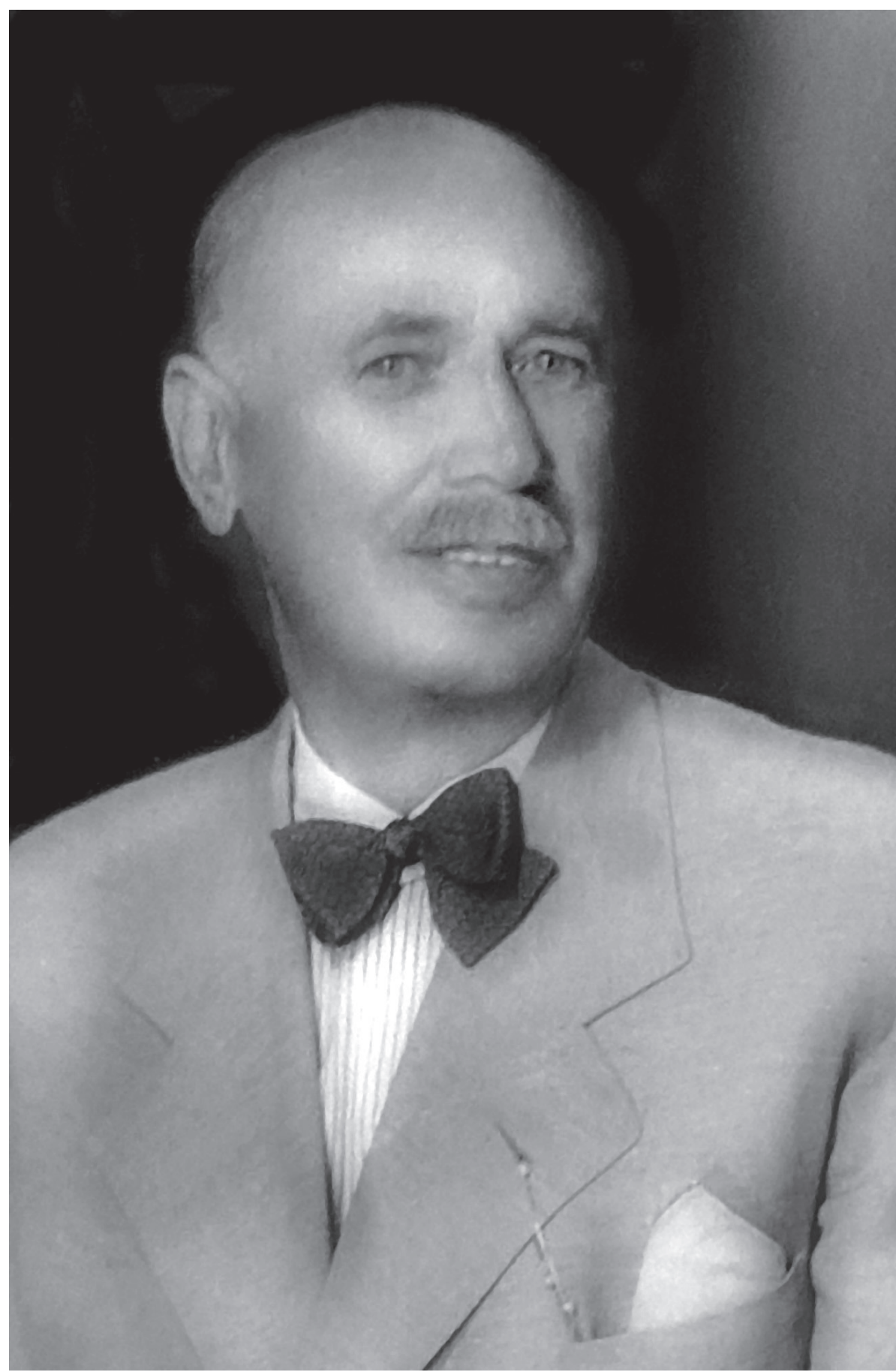

Slika 2. Franjo Urbany, prosinac 1942. (Obiteljski fotoalbum Marijana Urbanyja) 


\section{Arhivski izvori}

HR-DAZG-84-SSZ: Hrvatska, Državni arhiv u Zagrebu, Zagreb, fond 84, Sudbeni stol u Zagrebu, I.

HR-HDA: Hrvatska, Hrvatski državni arhiv, Zagreb:

- fond 78-PRZV: Predsjedništvo Zemaljske vlade.

- $\quad$ fond 79-UOZV-SDDS: Zemaljska vlada. Odjel za unutarnje poslove. Središnja defenzivno doglasna služba.

- $\quad$ fond 81-ZVOP: Zemaljska vlada. Odjel za pravosuđe.

- fond 143-SBOO: Savska banovina. Opće odjeljenje.

- fond 216-MNP NDH: Ministarstvo narodne prosvjete Nezavisne Države Hrvatske.

- fond 397-DN: Državno nadodvjetništvo.

- fond 501-PF: Pravni fakultet Sveučilišta u Zagrebu.

- fond 890-BHZP: Personalni spisi državnih službenika Zemaljske vlade, Pokrajinske uprave, oblasnih uprava, Savske banovine, Banovine Hrvatske i ministarstava NDH.

- zbirka 1363, Politička situacija (Grupa XXI).

- fond 1448-ZBMK: Zbirka matičnih knjiga i popisa obitelji.

\section{Mrežni izvori}

BillionGraves (1). Pristup ostvaren 10. 2. 2020. https://hr.billiongraves.international/grave/Marijan-Urbany/13117797.

BillionGraves (2). Pristup ostvaren 19. 2. 2020. https://hr.billiongraves.international/grave/Leon-Kaurić/11591396.

„Bošnjaković, Srećko”. Vinopedia. Pristup ostvaren 18. 2. 2020. http:// vinopedia.hr/wiki/index.php?title=Bo \%C5 \%A1njakovi \%C4 \%87, Sre \%C4 \%87ko.

Gradska groblja (1). Pristup ostvaren 10. 2. 2020. https://www.gradskagroblja.hr/default.aspx?id=382 [u tražilicu upisati „Milutin Urbany”].

Gradska groblja (2). Pristup ostvaren 27. 3. 2020. https://www.gradskagroblja.hr/default.aspx?id=382 [u tražilicu upisati „Berta Urbany”].

„Urbany, Marijan”. Hrvatska tehnička enciklopedija (on-line). Leksikografski zavod „Miroslav Krleža”. Pristup ostvaren 14. 2. 2020. https://tehnika. lzmk.hr/urbany-marijan/. 


\section{Tisak}

Hrvatski narod (Zagreb), 1941.

Jutarnji list (Zagreb), 1914, 1920.

Obzor (Zagreb), 1914.

Sloga (Karlovac), 1914.

\section{Literatura}

DESPOT, Igor. „Povjerljivi izvještaji obavještajnog odjela Generalštaba vojske Kraljevine Jugoslavije o ustaškoj emigraciji (Hrvatskom komitetu) 1937.1940.: dokumenti". Radovi Zavoda za hrvatsku povijest Filozofskog fakulteta Sveučilišta u Zagrebu 50 (2018), br. 2: 309-335.

FAK, Marko. „Aleksandar Ehrmann (1879-1965), veleindustrijalac i mecena (skica za portret)". Radovi Zavoda za hrvatsku povijest Filozofskog fakulteta Sveučilišta u Zagrebu 41 (2009), br. 1: 326-345.

HORVAT, Josip. Hrvatski panoptikum. Zagreb; Ljubljana: Globus; ČPG Delo, 1982.

Hrvatski djaci pred sudom. Stenogram sudenja hrvatskim sveučilištarcima u Zagrebu 1895. Zagreb: Dom i svijet, 1995.

JANJATOVIĆ, Bosiljka. „Državne uze, post i samica: suđenje Stjepanu Radiću 1920. godine.” Časopis za suvremenu povijest 29 (1997), br. 1: 97-127.

JANJATOVIĆ, Bosiljka. Politički teror u Hrvatskoj 1918.-1935. Zagreb: Dom i svijet, 2002.

JELIĆ-BUTIĆ, Fikreta. Ustaše i Nezavisna Država Hrvatska 1941-1945. Zagreb: Sveučilišna naklada Liber; Školska knjiga, 1977.

KEVO, Mario. „Djelatnost Međunarodnog odbora Crvenog križa u Nezavisnoj Državi Hrvatskoj (1941-1945)”. Doktorska disertacija, Sveučilište u Zagrebu, 2010.

KOLAR-DIMITRIJEVIĆ, Mira. „Jedno viđenje povijesti grada Koprivnice od 1901. do 1918." Podravina 8 (2009), br. 16: 5-28.

KOLAR-DIMITRIJEVIĆ, Mira. Povijest novca u Hrvatskoj od 1527. do 1941. godine. Zagreb: Hrvatska narodna banka, 2013.

KOSNICA, Ivan; PROTEGA, Martina. „Politička prava u Kraljevini Srba, Hrvata i Slovenaca: razvoj temeljnih obilježja”. Pravni vjesnik 35 (2019), br. 1: 139-156. 
KOTA, Miroslav. „Uloga Središnje defenzivno doglasne službe u Prvom svjetskom ratu”. Doktorska disertacija, Sveučilište u Zagrebu, 2019.

KRIZMAN, Bogdan. Ante Pavelić i ustaše. Zagreb: Globus, 1978.

KRIZMAN, Bogdan. Korespondencija Stjepana Radića 1919-1928, sv. 2. Zagreb: Sveučilište u Zagrebu, Institut za hrvatsku povijest, 1973.

KRIZMAN, Bogdan. Pavelić u bjekstvu. Zagreb: Globus, 1986.

KRIZMAN, Bogdan. Ustaše i Treći Reich, sv. 1. Zagreb: Globus, 1983.

MIKULAN, Miroslav. Povijest policije u Hrvatskoj. Varaždinske Toplice: Tonimir, 2003.

„Milutin Urbany”. Priroda 7 (1955): 278.

MIRNIK, Ivan. „Obitelj Alexander ili kratka kronika izbrisanog vremena”. Radovi Zavoda za hrvatsku povijest Filozofskog fakulteta Sveučilišta u Zagrebu 28 (1995), br. 1: 96-126.

MIRNIK, Ivan. „Referat dr. Viktora Alexandera caru Karlu”. U: 1918. u hrvatskoj povijesti. Zbornik radova sa znanstvenog skupa održanog u Palači Matice hrvatske 29.-30. listopada 2008. Zagreb: Matica hrvatska, 2012, 395-419.

Naredba od 10. januara 1922. broj 13.159 Pr.-1921. kojom se izdaju propisi o unutarnjem ustrojstvu Kr. redarstvenog ravnateljstva u Zagrebu i kr. redarstvenih povjereništava u Hrvatskoj i Slavoniji. Zagreb: Kr. zemaljska tiskara u Zagrebu, s. a. [1922].

„Naredba pokrajinskog namjesnika za Hrvatsku i Slavoniju od 10. januara 1922. Br. 13.159 - Pr.-1921., kojom se izdaju propisi o unutarnjem ustrojstvu kr. redarstvenog ravnateljstva u Zagrebu i kr. Redarstvenih povjereništava u Hrvatskoj i Slavoniji”. Policija (1922), br. 1-2: 83-90 i (1922), br. 3-4: 193-201.

„Novine u zagrebačkoj policiji”. Policija (1924), br. 9-10: 393-394.

„Policijska konferencija”. Policija (1923), br. 21-22: 869-870.

„Prof. Milutin Urbani. Prigodom 50-godišnjice života i 30-godišnjice rada”. Gospodarske novine (1927), br. 7: 75-76.

RAHTEN, Andrej. „Ozadja iz okoliščine Žibertove teorije zarote”. U: Žibertova teorija zarote. Ljubljana: Založba ZRC, 2013, 3-18.

SIROTKOVIĆ, Hodimir. „Pravosudne strukture u hrvatskim zemljama od 1918. do 1945. godine”. Vjesnik Istarskog arhiva 1 (32) (1991): 17-30.

STIPANČEVIĆ, Mario. „Mlada Jugoslavija - teroristička ispostava zagrebačke policije”. Arhivski vjesnik 62 (2019): 127-155.

STIPANČEVIĆ, Mario. „Stranputice Joje Vragovića. Ulomci biografije jednoga zagrebačkog policajca”. Časopis za suvremenu povijest 52 (2020), br. 1: 101-130. 
STIPANČEVIĆ, Mario. „U obrani ‘̌uftova i dreka’. Počeci redarstvene karijere Janka Bedekovića”. U: Zbornik „Konac Velikoga rata”. Zagreb: Hrvatski državni arhiv, 2020, 219-221.

STIPANČEVIĆ, Mario. „Vampir iz Petrinjske. Obris portreta Janka Bedekovića”. Gordogan (2017), br. 35-36: 104-128.

URBANI, Franjo. „Zagrebačko redarstvo”. Policija (1923), br. 17-18: 676682.

VRAGOVIĆ, Aleksa. „Kratki prikaz razvoja redarstva u Zagrebu”. Policija (1924), br. 17-18: 671-675.

VRAGOVIĆ, Aleksa. „Reorganizacija naše policije”. Policija (1924), br. 1516: 585-593.

VRAGOVIĆ, Aleksa. „Uvod. Kratki prikaz razvoja redarstva u Zagrebu”. $\mathrm{U}$ : Zbirka propisa o organizaciji redarstva u Zagrebu. Zagreb: Kr. redarstveno ravnateljstvo u Zagrebu, 1924, 1-4.

„Zaključci doneti na policijskom kongresu u Zagrebu”. Policija (1923), br. 23-24: 914-916.

Zbirka propisa o organizaciji redarstva u Zagrebu. Zagreb: Kr. redarstveno ravnateljstvo u Zagrebu, 1924.

ZORKO, Tomislav. „Ženska prostitucija u Zagrebu između 1899. i 1934. godine”. Časopis za suvremenu povijest 38 (2006), br. 1: 223-241. 


\section{SUMMARY}

\section{Franjo Urbany, a Minion of the Karađorđević Regime}

Like his numerous contemporaries from the period of the dissolution of Austria-Hungary and establishment of the new Yugoslav state, Franjo Urbany (1874-1951), a lawyer from Zagreb, General Attorney and police chief of the second-largest city in the Kingdom of Serbs, Croats and Slovenes, had to make a considerable political and ideological U-turn in order to continue his presence in high administrative circles. It would be hard to say whether his personal pre-war views were in opposition to the new situation or not, but there can be little doubt that he wanted to ingratiate himself to the new power-holders. This was a necessity if he were to continue climbing the administrative ladder in the new environment. The difficulty was that Urbany, like many of his kind from the occupying system, had to virtually jump into the lap of those who had been occupied up until that point and - in the new circumstances - were the leading political forces of the state union of which Croatia had suddenly become a member. There can be little doubt that Urbany knew how to adapt. Once a participant in the burning of a Hungarian tricolour at Zagreb's Jelačić Square in 1895 and a minor administrator of the Austro-Hungarian occupying forces in Serbia during World War I, he became a persecutor of the Croatian opposition and a campaigner for the protection of the centralistic and unitarian Yugoslavian community ruled by the Karađorđević dynasty. These merits provided him with the opportunity to lead and restructure the Zagreb police in the period of 1921-1924. Despite his successes, it appears that the power-holders were in search of a firmer hand for the upcoming times, in order to combat the increasing numbers of dissenters. Because of this, Urbany was forced to resign as the chief of Zagreb's police and was succeeded by the notorious Janko Bedeković.

Key words: Franjo Urbany; biography; Zagreb police; monarchist Yugoslavia 